Article

\title{
Understanding Private-Sector Engagement in Sustainable Urban Development and Delivering the Climate Agenda in Northwestern Europe-A Case Study of London and Copenhagen
}

\author{
Roudaina Alkhani \\ School of Architecture and Cities, University of Westminster, FHEA, London W1W 7BY, UK; \\ r.alkhani@westminster.ac.uk
}

Received: 8 August 2020; Accepted: 17 September 2020; Published: 13 October 2020

\begin{abstract}
While greenhouse gas emissions in Europe have reduced in recent years, there is still a considerable gap between the current situation and where we need be to limit global warming and adapt to climate change, particularly in cities. The Sustainable Development Goals and the Climate Agenda have placed great emphasis on collaborative frameworks and the private sector's crucial contribution to closing the climate gap in terms of investment and leadership in innovation. However, there has not been a concise follow-up and assessment of the private sector's practical involvement and contribution, whether policy and legislative frameworks and planning approaches are suitable to enable this involvement, and who would lead in delivering the climate agenda locally. The present article addresses this gap reporting on case observations regarding the delivery of climate interest and sustainability through urban development in London and Copenhagen-two European cities of different sizes and varying government approaches. Thereby, the article assesses patterns of private-sector involvement and governance around climate adaptation and mitigation and locates gaps around its involvement in delivering the climate agenda. The analysis clarifies overarching differences in governance and frameworks for the involvement of the private sector between the two cities, attributing this on the local level partly to city size and scale, but to a great extent to 'city leadership' in the built environment and sustainable urban innovation in general. A crucial finding highlights the importance that cities further establish platforms for collaborative learning, specifically around pilot urban projects, thereby stimulating voluntary private engagement. Another key finding is in the potential effectiveness of strategies by public agencies such as city governments to incentivise private actors and simultaneously monitor sustainability effects both broadly at the city level, and specifically at urban project level using ecological, circular and life-cycle approaches. Further implications of the analysis point to the importance of developing a more nuanced approach to understanding the different roles fulfilled by the 'private sector' in the built environment and the necessity of creating an information base addressing the life cycle of development projects and business processes and comparing their impacts. The situation also necessitates considering efforts, impacts, climate finances and data on the broad city scale. The findings of this article can inspire further research, benefit further action in these cities and inform international efforts about climate gaps related to climate adaptation and mitigation.
\end{abstract}

Keywords: climate gaps; climate policy; climate governance; private sector contribution; climate data; sustainable development; city leadership; ecological place-making 


\section{Introduction}

As a follow up on the SDGs [1], the WMO Climate Agenda [2], the 2015 UN Climate Change Conference [3], and the UN Climate Action Plan 2020-2023 [4], world governments have generally committed to engaging their societies in delivering sustainability and climate agreements. These commitments apply principally to activities in and policies for cities and urban environments in general [5]. The implementation of these agendas is far from on track, and the UNEP's Emission Gap Report of 2019 raised the alarm that there still is a considerable gap between the current situation and where we need be to limit global warming by the end of the century to a maximum $2{ }^{\circ} \mathrm{C}$. The collective effort to stop the increase in global GHG emissions has failed to reach the target. The 2019 Emission Gap Report highlights that only a few countries have formally submitted long-term strategies to the United Nations Framework Convention on Climate Change (UNFCCC) despite the increasing number of countries announcing net-zero GHG emission targets for 2050 [6]. It concludes that countries 'need to increase their NDC ambitions [Nationally Determined Contributions in greenhouse emissions] threefold to achieve the well below $2{ }^{\circ} \mathrm{C}$ goal and more than fivefold to achieve the $1.5^{\circ} \mathrm{C}$ goal.' The problems can be located at different levels and for both public and private actors. They relate to the state of the art of climate adaptation measures, but also the lack of accurate information on climate impacts on the different sectors including market and nonmarket impacts, hereunder health and energy demand, and climate risks [7], which should have prompted the instigation of climate adaptation and mitigation measures. At the EU level, despite registered reductions in gas emissions [8], the European Environmental Agency points to gaps and to the fact there is no systematic follow-up and that few European countries have identified concrete investment needs and plans to implement their national climate and energy objectives [9].

Cities have a key role in addressing these climate challenges. Urban environments feature a wide range of climate-change impacts, including reduced air quality, changing temperatures, flood risk, the threat to assets and human health, and pressures on natural resources. The severe impacts on vulnerable communities have also been stressed by several leading organisations, including RTPI [10]. At the same time, cities feature considerable capacities to dealing with these impacts $[5,11]$, including public capacities to initiate and lead sustainable urbanism and coordinate action plans, and private capacities to provide innovation, finance, and knowledge. Recent years have witnessed an increasing awareness of the role that the private sector can play in facing climate challenges and contributing to sustainable development [12]. However, a key problem is a persistent lack of understanding internationally of the form of private sector engagement in sustainable European built-environment practice and the collaborative practices involved [13]. Another problem is the lack of consistent methods for assessing its involvement. More insight is clearly required in how private businesses might be involved in government-led forums for sustainable urban development [6]. These problems are the key points of departure for the paper.

Despite an increasing emphasis on a multi-stakeholder approach to managing risks, including climate [14], there is a tendency in the debate to make general references to 'private sector involvement' without systematically setting out what actors may be included, what forms of engagement are implied and what elements are included in assessing private involvement. Lorenz et al. [15] highlighted the need for a better understanding of which organisations can be taking on key responsibilities in climate planning. Still, knowledge about the different forms of private sector involvement in urban development and planning at all levels, studied in context, is generally limited and may easily lead to either simplistic expectations to the private sector's resources or pessimistic conclusions around negative impacts on urban development. These kinds of generalisations typically end up with inaccurate accounts and expectations for the private sector in closing the climate gaps and inadequate responses. The increasingly international focus on sustainability and ecology has formed a turning point in perceptions of private sector roles. This change has featured more engagement by the private sector generally. However, more contextual understanding is needed, such as private sector roles in different city areas and various types of projects. Also, the settings by which cities have 
committed to private-sector engagement need to be further established [16]. Therefore, this paper asks what form of private sector engagement may feature in European sustainable urban-development practice, and specifically for strategic cities like London and Copenhagen. The focus of the paper is on clarifying local private sector involvement and private sector contributions with regards to the delivery of sustainability and climate goals in European cities. The aim is also to consider the potential effectiveness of the policy, governance, and planning and regulative frameworks relevant to new urban development and existing urban areas. The paper also seeks to clarify practical choices around sustainability-related knowledge and the potential relevance of shared information bases using agreed methods and approaches to allow bottom-up local and national action, monitoring, and assessments. A final aim is to identify options for improving engagement, including possibilities to incentivise the private sector. Answering these questions will make a significant contribution to the ongoing debate, research and professional practice related to sustainability. It will also help closing current climate gaps at all levels.

In the subsequent sections, the article will first explain its methodology for the research, followed by a more general discussion regarding forms of involvement of the private sector in urban development, sustainability, and climate initiatives. It will then explore evidence for answering its key research question for two case studies: London and Copenhagen. The article finalises with a discussion of findings in a comparative approach, and it highlights lessons from the two cities and critical recommendations.

\section{Methodology}

The main methodology for the paper consists of a literature review followed by a qualitative case-study analysis. The aim of the literature review is to establish a current generic understanding of the role of private-sector actors in practices of sustainable urban development. A wide range of keywords analogous to 'private sector' and 'sustainable urban development' were used in a library system based on Web of Knowledge. Section 3 presents a framework listing typical private-sector roles, which are then used to structure the case-study analysis in Section 4 . The framework enables the assessment of private-sector's roles, including involvement in climate action, contributions to policy processes and partnerships, innovation initiatives, and acknowledgement of impacts.

The paper's key methodology to explore the role of the private sector in delivering the sustainability and the climate agendas in specific contexts involves case-study analysis on urban-development and sustainability in two European cities (London and Copenhagen). For both cases, a survey of the landscape of major actors was performed as well as a document analysis, focusing for both cases on a combination of documents from (1) national guidance and legislation relevant for climate policies, sustainability and urban planning; (2) actual city plans, and sector reports relevant to climate adaptation and urban development; and (3) reports by relevant private platforms and networks. Descriptive climate accounts have also been consulted for both cities and their countries. The analysis establishes how sustainability and climate policies and legislations framing the private sector's involvement have been framed at all levels, synergies across levels and among actors, and the strength of the framework they create around the private sector's engagement. It also reveals the role of relevant private platforms and networks.

Table 1 provides an overview of the documents involved [17-65]. The policy documents and reports' relevance were determined based on categories suggested through UNEP (2019) [6] and IPCC (2019) [66]. These categories include climate adaptation, carbon reduction, renewable energies, stormwater, and rising sea levels. 
Table 1. Data used in document analysis.

\begin{tabular}{|c|c|c|c|}
\hline & National Actors, National Guidance, and Legislation & $\begin{array}{l}\text { Local Actors, City Plans and Sector Reports Relevant to Climate } \\
\text { Adaptation and Urban Development }\end{array}$ & Reports by Relevant Private Platforms and Networks \\
\hline London & 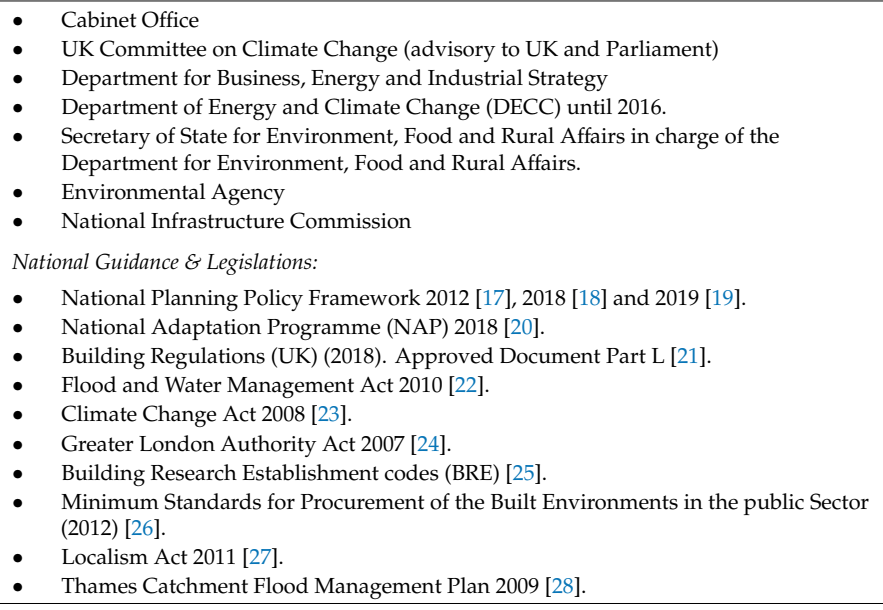 & 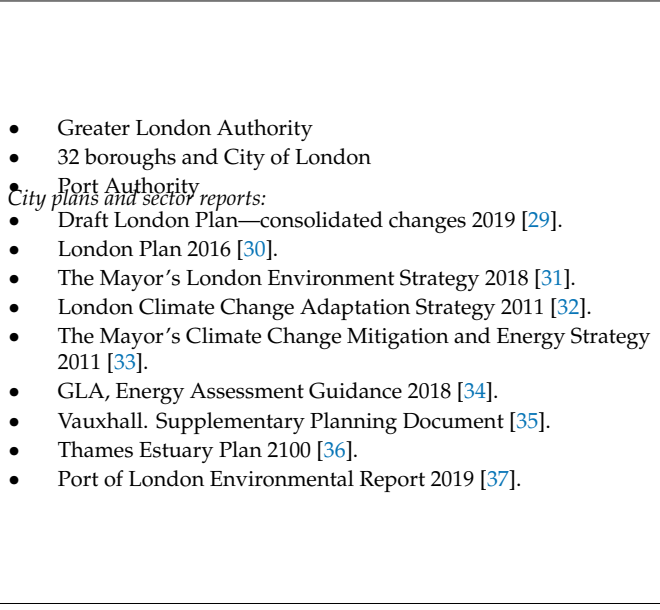 & $\begin{array}{ll}\text { - } & \text { London Climate Partnership (LCCP) } \\
& \text { UK Green Building Council (UKGBC): Net Zero Carbon } \\
& \text { Buildings: A Framework Definition [38]. } \\
\text { - } & \text { London Energy Transformation Initiative (LETI): Climate } \\
& \text { Emergency Design Guide [39]; Embodied Carbon Primer [40]. } \\
\text { - } & \text { Building Research Establishment.: } \\
\text { - } & \text { Future of London Network: Housing Delivery Models [41]. } \\
& \text { Royal Town Planning Institute: Five Reasons for Climate Justice } \\
\text { in Spatial Planning [10]. } & \end{array}$ \\
\hline Copenhagen & 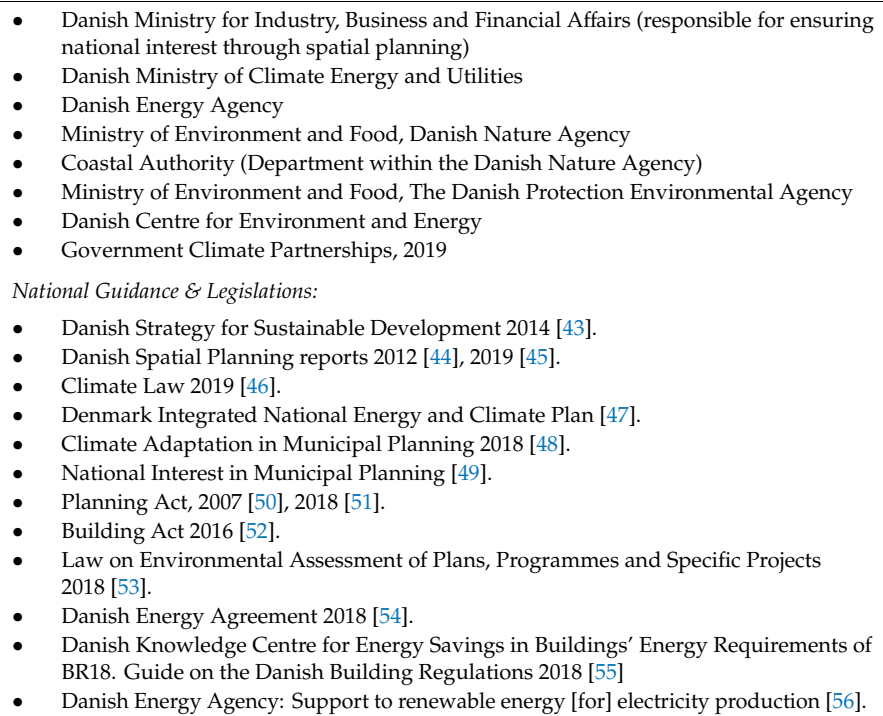 & $\begin{array}{l}\text { - City of Copenhagen } \\
\text { By \& Havn ((publicly owned company but driven on } \\
\text { commercial principle) } \\
\text { City plans and sector reports: } \\
\text { - Municipal Plan 2019 [57]. } \\
\text { - } \quad \text { Municipal Plan 2009/ [58]. } \\
\text { - Copainable Copenhagen Strategy } 2007 \text { [59]. } \\
\text { - Copenhagen Cimate Adaptation Plan 2011 [60]. } \\
\text { - Copenhagen First Climate Resilient Neighbourhood } \\
\text { Strategy [62]. } \\
\text { - Arhusgadekvarteret i Nordhavn (local plan proposal) [63]. } \\
\text { - City of Copenhagen Sustainability tool [64]. } \\
\text { - Copenhagen Eco-Friendly Neighbourhood International } \\
\quad \text { Competition North Harbour. Launched by By\& Haven [65]. }\end{array}$ & $\begin{array}{l}\text { - Association and Project Energy Lab Nordhavn } \\
\text { COWI: Development of a number of tools to put a price on } \\
\text { companies' climate footprint and assess impacts. Support to } \\
\text { companies' Natural Capital Accounts (NCA) } \\
\text { CopenhagenX (urban and housing exhibition 2002-2012) } \\
\text { supported by Realdania (private org, in collaboration with the } \\
\text { City of Copenhagen, Frederiksberg municipality and Danish } \\
\text { Architectural Centre }\end{array}$ \\
\hline
\end{tabular}


Information on institutional and broader policy context related to the urban plans and reports listed above was collected to cover approximately a period over 10 years from 2009 to 2020, both for London and Copenhagen. These consultations underpin the analysis examining current climate policies and city plans. An additional factor for the Copenhagen case is that the author was involved in project management for the City of Copenhagen between 2006 and 2009, thereby obtaining fundamental insight into the institutional arrangements relevant for sustainable-development policies in this case.

Overall, the article reports case observations on urban development and sustainability in two European cities, London, and Copenhagen. The selection of these two cases is motivated by the relatively strong position both cities have in establishing innovative sustainability policies, combined with institutional differences in private sector engagement. Copenhagen has been generally accredited for its advance in sustainability, climate efforts, and collaborative governance and was identified as European Green Capital in 2014. London has been earmarked as a leading capital in climate efforts and is a top-ranking city in the global Sustainable Cities Index. In recent years, both cities have made steady steps towards clean energy, energy efficiency, and sustainable development, engaging with various eco-innovation projects and addressing the rise in water levels, floods, and extreme weather conditions.

\section{Role of the Private Sector in Climate Responses}

This section aims to clarify typical variations of private sector engagement in sustainable urban development. The international literature generally acknowledges the importance of the private sector in delivering climate goals, typically based on a partnership or collaborative approach involving all sectors and emphasising the role of cities, public agencies, and civil society [13] [67-69]. There is a growing reliance on the private sector's contributing role, suggesting that governments cannot singularly manage urban development and drawing attention to benefits related to private-sector involvement in urban development [70].

Clearly, involving the private sector can help in terms of capacities as no local or national government can mobilise necessary capital and political consensus to make effective investments in infrastructures leading to sustainability. Macomber [71] argued that there is an 'unrecognized opportunity for the private sector to engage in selective investments that can help cities limit the effects of these trends [meeting the need of urbanisations and shortage of resources, energy, clean air]'. A related idea is that private parties can be incentivised to mobilise their capacities through offering rewards. Henry [72] highlighted that 'if we can match up explicit and meaningful rewards for voluntary action, with robust mechanisms that deliver verifiable climate outcomes, the private sector will make a material contribution to closing the emissions gap'. At the same time, these contributions would be broad ranged. Emissions-reduction and stormwater-adaptation projects also deliver other benefits than climate adaptation and mitigation, such as health improvements and biodiversity conservation, and can be part of more holistic plans contributing to social, environmental, and economic benefits.

Who is the private sector?

To understand the current and potential contribution of the private sector to the delivery of the climate agenda, it is important to highlight what we mean with the 'private sector' and patterns of its involvement in urban development and sustainability and to bring a reflection on its commitment to the sustainability goals. The article focuses on the 'private sector' engaging with the built environment as an overarching term including diverse individual professionals and companies interacting in diverse associations with each other, and with the public agency and the community;

- Investors, land, and business owners. These include individuals and companies, private financial institutions, pension funds companies, and public estate companies acting as private bodies and blurring the line between 'public' and 'private'.

- Developers and contractors.

- Architects, engineers, landscape and urban design/planning practices working for the city or any public or private sector clients or private people. 
- Consultants to the public or private actors involved in $R \& D$ and capacity building (knowledge providers).

- Service managers facilitating interaction between local authorities and private contractors or communities.

- Service providers, for example, transport, energy, and waste companies.

- Businesses involved in the production of climate technology, hereunder renewable energies, such as windmills and solar cells, etc.

\subsection{Impact through Internal and External Processes}

The groups mentioned above often work in networks, where for example, developers engage architects, consultancy firms, and business managers in construction and urban development processes. Here many questions can arise around whether these processes are optimal, supporting the integration of functions, circularity, sustainability, and climate interest throughout the lifecycle of projects from conception to implementation phases and later maintenance and in terms of associated environmental, economic, and social impacts in urban areas. For example, it may be crucial for urban projects to explore whether sustainability concerns are an integral part of project design. Another aspect is the extent to which sustainability report recommendations get integrated into the projects' concepts and whether quality steering processes are generally well designed. These aspects typically need to be assessed and monitored.

Private actors involved in sustainability practice, whether occupying a space, involved in industrial production, in construction or service delivery (water, waste) ought to be committed to reducing $\mathrm{CO}_{2}$ emissions through internal and external processes in compliance with national and local regulations. They should be committed to designing products and processes to limit $\mathrm{CO}_{2}$. Efficiency in buildings and reduction of $\mathrm{CO}_{2}$ through the inclusion of different measures has been encouraged by the World Green Building Council, and by national and local governments and planning and building regulations. In recent years, there has been an increasing focus on circularity in construction and business processes, including a major role by the European Investment Bank [73] and the MacArthur Foundation [74] inviting private actors to design products and processes that limit and compel the use of finite resources in cities, including water, electricity, and land to contribute to healthier eco-systems. This takes place along with an increasing focus on circular economies inviting to review business processes and reduce consumption of materials and waste throughout the product life. Here it is crucial to develop relevant databases based on appropriate methods to communicate climate contributions.

\subsection{Role in Partnerships for Urban Development and Sustainability}

Since the end of the 1970s and the 1980s and with the difficult economic situation facing many public authorities, local authorities have increasingly engaged with private partners to meet public budget constraints and link resources around development [75]. There has been a strengthened emphasis on the involvement of private actors in city development through public-private partnerships. This has been the case, especially in urban regeneration projects, as the development of outmoded industrial and port sites in the North European cities posed a significant challenge. The complexity involved in the regeneration of these sites regarding scale, environmental context, urban form, ownership, and regulatory frameworks prompted new planning and organisational frameworks, involving several actors to join efforts and share risks. They elaborated on the understanding that neither the public sector nor the private sector alone can meet the challenge [75]. Cases such as the regeneration of the London Docks and the Copenhagen harbour reveal the genesis of these governance forms and their evolvement. The UK Conservative Government in the 1980s focused on linking private investment in the regeneration of declining areas in British cities in the framework of centralised public agencies 'Urban Development Cooperations' and softened planning regulations, including the launch of free development zones. This approach led to the creation of the London Docklands Development Corporation (LDDC) in 1981 to facilitate private investments in the Docks. However, criticism of its 
operation prompted the creation at the end of the 1990s of the Urban Regeneration Company (URC) under the National Regeneration Agency as private companies aimed at linking public and private sector partners in the context of a broader Strategic Regeneration Framework. The URCs benefited from public subsidies while leading urban regeneration programmes with a greater social-economic context, and more horizontal planning styles to promote sustainable development through the regeneration process. Reconciling the different interests and involving the local communities were two major aims of URCs aimed at more inclusiveness [75]. While recent years have witnessed a growing focus on local communities' role, tension is still present between the different interests and conflicts with the main target of sustainability.

Many researchers observing international cases have characterised the change in urban governance from traditional public administration to new public management e.g., Hood [76] to new public governance highlighted by Osborne [77], accommodating private investments while involving the community. Alkhani [75] highlighted the rise of new forms of consortiums in the 2000s in North European urban regeneration involving multiple local and international private actors, public agencies, and privately owned public companies with a blurred line between public and private actors and light involvement of communities.

There is inconsistent evidence about the benefit of these regeneration projects and investments, the extent they have served public benefit, provided high-quality environments, and contributed to sustainability. Moore and Bunce [13], for instance, established that the reality on the ground demonstrates that the increasing reliance on private sector resources and skills in the delivery of sustainable urban environments has been problematic and tends to result in expensive housing and increasing land values in both new and urban regeneration areas. Moore and Bunce referred to the generic design of many projects, inequitable access, and underregulated design quality compliance as 'complicating the aspirational intentions of policymakers dependent on the private delivery of the 'public good' of sustainability.'

Public-private partnership agreements have been a much-used instrument in urban development; nevertheless, several academics have criticised their use, e.g., Koppenjan and Enserink [78] for favouring private sector interests. The critique also includes the mixed evidence on their contribution to long-term sustainability objectives, referring to ambiguity around how effectively PPPs contribute to ecological, social, and economic goals. Pinz et al. [79], who conducted a systematic review of the business and public administration literature in the past decades, raised doubt about whether PPPs deliver the sustainability-related objectives they typically set out. A key aspect of this kind of literature is the emphasis on the importance of concise regulatory frameworks for supporting the successful implementation of PPPs and an emphasis on externalities: A commitment by relevant private actors to address and mitigate environmental impacts from development clearly. Private sector actors can internalise environmental impacts into their own production processes and development projects, and thus their management commitments.

In the absence of relevant frameworks, neither public nor private sector investments guarantee delivering qualities associated with sustainable development. It is crucial to ensure well-integrated, new thinking planning approaches, and supportive planning, collaborative and legislative frameworks [75]. A focus on sustainability approaches as a commitment to the SDGs in cities also calls for integrated approaches in urban development and regeneration, and it highlights the benefit of collaboration, including local communities. Here is another challenge framing the private sector's involvement that requires further exploration.

Ensuring that climate and sustainability goals are included in existing, and new urban regeneration areas implies an in-depth understanding of private sector contributions in different contexts, and the types of incentives that can be relevant while promoting climate and sustainability justice. It also requires the setting up of integrated and visionary planning approaches based on an exploration of benefits and impacts in specific contexts at multiple scales. 
Meanwhile, it is also essential to highlight the multiple opportunities through urban regeneration to restore ecological damage in cities and combat decline in inner cities [80]. Lehmann (2019) [81] has recently highlighted the potential of inclusion of climate measures to encourage connectivity between existing and new eco-systems within cities and at the peri-urban fringes through nature-based solutions and 're-naturing' neighbourhoods to cope with climate change. The contribution of these measures, such as SUDS (sustainable urban drainage systems) to deliver healthier and liveable cities, is also emphasised in recent research [82,83]. Not only does the delivery of such a vision depend on a collective vision that ought to be collaboratively developed by local governments and governments, developers, communities, and university as Lehmann [81] emphasises, but will encourage strong place-making and more connected communities [80].

Partnerships for urban development and sustainability have recently included a sharper focus on the potential of nature-based solutions (NBS) in cities. In its report 'The NBS for Climate Manifesto', UNEP emphasises that NBS can contribute to cost-effective climate mitigation needed between 2020 and 2030 [84]. NBS can be essential for sustainability, contributing, for example, to stronger ecological values, food safety, and livelihood resilience. The private sector parties should commit to NBS and using finite resources in cities (including green, water, air, land) in a much more responsible way, and help to work with renewable sources overall [70]. Environmental risks, including pandemic risks, have recently drawn attention to the importance of 'Green Recovery' involving a focus on health, ecology, and climate concerns together and calling for joining efforts [85]. While the above emphasises that planning for climate adaptation and mitigation should be closely linked to urban development, it is essential to remind that one of the main challenges facing planning for climate resilience resides in the fact that planning and commitments need to be adaptable to uncertain futures. This might be challenging for private actors who aim at more clarity and secure investments. The situation, therefore, requires more flexible and paradigm-breaking planning and collaborative frameworks [86]. Equally, meeting the 'Green Recovery' requires addressing planning, legislative and funding frameworks, and potential collaborations, including the private sector's involvement through more innovative frameworks.

\subsection{Sustainability Innovation}

Another essential role of the private sector is its expected leadership in business and industrial innovation related to climate change and sustainability either individually or as a part of public-private partnerships [87]. The OECD [88] highlighted in 2015 that any effort to limit greenhouse gas (GHG) emissions requires complementary science and innovation policies pointing to the private sector's indispensable role. Involvement can include:

- Contribution to developing new technologies and new business processes around low-carbon infrastructure and investment in sustainable technology, which can reinforce more aware private-sector contributions in cities. This includes companies in the renewable energy sector manufacturing solar energy panels and systems, windmills, etc. In the UK, these kinds of investments tend to increase solar capacity as highlighted by Green Match.

- Contribution to the development of new building/infrastructure models involving technological innovation, for example collaboration around eco-buildings/city models targeting 0-carbon objectives and reductions in greenhouse gas emissions and water use.

- Contribution to the development of new business processes and governance, new planning aspects, and new tools.

Johnstone and Pilat [89] argued that in the climate area, there is evidence that young firms are a relatively more important source of technological innovation-these have been the avantgardes in the revolution of information systems. The authors emphasised the importance to understand the links between business dynamics and the emergence of radical technologies and call to support the young firms. These authors identify many of the GHG-intensive sectors, such as energy and transport as large network sectors with long-term engagements in capital and skills that can act as additional barriers 
to firm entry and innovation. They recommend therefore that good framework policies encouraging experimentation are essential where trial and error are accepted.

However, considering the broader landscape, multinational companies seem to expand territory, especially in combined renewable energy systems. Some of these companies are government-owned like the Finish Government-owned Fortum and the Swedish Government-owned power company Vattenfall—which operate as private actors outside their nations, with the latter generating power in Sweden, Denmark, the Netherlands, Germany, and the UK. Waste recovery is another area where major actors have taken monopoly as the Nordic Energy Group, ST1. This demonstrates the complexity of assessing private investment's contribution and that generalisation should be avoided.

On an urban level, Himmel and Siemiatycki [90] highlight the importance of understanding what is meant with 'innovation'. They point out that innovation can be linked to plan concepts and processes. Schot and Steinmuller [91] highlight the private sector's significant role in delivering 'Transformative Innovation Policies' related to climate change as they require a radical change of existing solutions and processes. Madsen and Mikkelsen [92] argue that climate knowledge and perceptions of climate risks impact urban innovation processes and lead to new technological pathways of innovation and institutional decision-making routines. Uyarra et al. [93] draw attention to the private sector's role through public procurement processes generally, which function as tools for local innovation. These processes have important potentials to drive innovation through competitiveness and search for untraditional solutions, for example, through tenders and closed or open competitions. Meanwhile, Uyarra et al. discuss several barriers influencing innovation related to processes, procedures, and poor management of risks.

In a study of the innovative aspects in waterfront regeneration and sustainability, Alkhani [75] identified innovation in urban projects as linked to inclusion of sustainability technologies, more integrated approaches aiming clearly at multiple benefits and environmental, social and economic sustainability, and new plan and urban design ideas. She also pointed to new use of land, flexibility, adaptability and adaptive reuse of the built environment, as well as to new forms of collaboration, funding and quality steering. The latter could for example include approaches to environmental management. Still, there are few studies on the impacts of climate change policies on innovation and the private sector's involvement [94]. It also seems that there are many ambiguities related to how to understand innovation, and therefore the possibility to assess its impacts, enable it, and create a good information base. The literature evolved in the recent years with more examples of some innovative urban concepts as the inclusion of rain gardens, SUDS, and green walls.

Innovation also implies that the private sector contributes in terms of engagement in research and influential debate, for example around the range of internationally used assessment tools for measuring resilience as developed by consultancy firms like ARUP, AECOM and other consultancies. An example is the Disaster Resilience Scorecard, which AECOM and IBM developed in 2017 for the United Nations Office for Disaster Risk Reduction as an operational tool of the Sendai Framework of Disaster Risk Reduction 2015-2030, including climate change, to be used at the local level. This toolkit provides a set of assessments structured around the UN Essentials of Disaster Resilience, including overarching Sendai Framework targets and detailed assessments that involve multiple stakeholders. The toolkit aims to help local authorities understand resilience, anticipate and prepare for disasters, mitigate risks, and recover. It helps them identify strategic areas of intervention to reduce risks and suitable governance and to adjust future policies [95]. This tool was, for example, used by the Association of the Greater Manchester Authorities. Also, the City Resilience Index, which Arup developed in collaboration with the Rockefeller Foundation 100Resilient Cities program, enables cities to understand their resilience and prioritise policies, actions, and investments based on a set of indicators and goals specifying primary objectives [96]. Further private-sector led contributions emerge from larger industrial firms involved in for example infrastructure engineering, construction, and smart technology. 
Overall, the literature review here points to the following variations of private sector engagement in sustainable urban development:

- Private sector parties' contribution to clarify and stimulate the prudent use of resources typical for urban environments: Green, water, land, air. This role is characteristically reflected in practices of project development and construction, and nature-based and climate-adaptive solutions. How can the private sector contribute proactively and ethically?

- Private sector actors' engagement in assessing the environmental impacts from the urban development changes they facilitate or initiate. This role typically involves impact assessment and discussions around compensation and mitigation for environmentally damaging effects of urban development. How can careful environmental considerations at the early stages and as an integral part of project concepts be encouraged?

- Private sector actors' contribution in terms of investments into technological innovation, experimentation, and smart technology. This role in general features private firms as $R \& D$ investors, providers, and facilitators of sustainable public facilities, technologies, and urban infrastructures. How can innovation, experimentation, and knowledge bases be supported and incentivised?

- Private parties' involvement in public engagement aimed at imagining, partnering, and evaluating sustainable futures. How can this role be strengthened through collaborative governance, including a negotiated or wider integrated communicative role for private parties in contributing public benefits?

This overview shows distinct, yet intersecting forms of private sector engagement in sustainable urban development. The overview will serve as a framework for reviewing the cases in the analysis below.

\section{London and Copenhagen-Two Case Studies}

On a national level, both the UK and Denmark have emphasised sustainability goals in their national and spatial planning policies since the 1990s following the Brundtland Report, and it is useful to notice that both countries have since then succeeded in reducing their emissions. The UK has succeeded in reducing its greenhouse gas emissions by over 40\% between 1990-2020 [97]. Still, large parts of the UK's economy are dependent on fossil fuels, placing much responsibility in the hands of the private sector in the UK's market economy [41]. A great gap relates to the adaptation of UK homes. A recent report by the Institute for Public Policy Research (IPPR) [98] reveals that 12 million homes in the UK likely need to be energy retrofitted over the next 30 years to meet the UK's 2050 net zero target. The report estimates that almost $£ 10.6$ bn a year of private and public investment will be needed in England until 2030.

Denmark has also succeeded in reducing emissions. According to Danish Energy Agency, Denmark's collective emissions have dropped by approximately $20 \%$ since 1990 due to more efficient energy use and increased use of renewable energy sources, hereunder solar and wind. The Danish Parliament agreed in 2019 on a legally binding national Climate Act with a legally binding target to reduce greenhouse gas emissions by 70 percent by 2030 (compared to the 1990 level) and net-zero emissions by 2050. In parallel, a national Climate Partnership between the government and businesses was established in 2019 to find solutions for climate challenges [99]. The Danish context displays a strong emphasis on private sector involvement supported by the public sector.

Both London and Copenhagen have been engaged in delivering national policies in their countries and in taking a role in climate leadership. As a starting point, London has according to GLA succeeded in reducing its $\mathrm{CO}_{2}$ emissions in 2017 with 33\% on 1990 levels [100]. This reduction is slightly below the UK level in the same period and invites us to explore the underpinning factors. Like Copenhagen, London has cut more significantly down on its $\mathrm{CO}_{2}$ emission levels in recent years, achieving a $40 \%$ reduction since the peak emission in 2000 [100] and reduction in the per capita emission reaching 3.4 
tonnes in 2017 [100]. Copenhagen has also claimed successes in cutting its $\mathrm{CO}_{2}$ emissions, for more than $20 \%$ between 1990 and 2005 [101], and over 40\% between 2005 and 2018 [102], which is above the national levels and demonstrates the city's leadership in addressing climate challenges. Copenhagen's reduction of $\mathrm{CO}_{2}$ emissions per capita is more significant than London, with emissions reducing from 5 tonnes in 2005 to 2.5 tonnes in 2018 according to Copenhagen's climate accounts. While these figures are indicative to our study and reflect the efforts made in the renewable energy sector as stated in the two cities' documents, we need to appreciate the impacts of these two cities' policies, governance, and organisational frameworks around implementing adaptation and mitigation policies through different sector programmes, physical planning, and urban development in existing and urban regeneration areas.

On the overarching level, national institutional organisations and planning regulations play a major role in determining existing and emerging institutional infrastructure and all laws around climate, environment and sustainability and funding sources, and how they are linked to urban development at the local levels. These frameworks and related patterns of government reflect the political environment and its changes, as revealed in a significant number of studies. For example, the evolving forms of the UK regeneration partnerships and the extent they targeted engagement with local authorities and communities reflected shifts between Conservative and Labour governments. Bailey [103] highlighted that The Localism Act [27], which was adopted by the UK Government in 2011, was the product of the coalition government's formation in 2010. It both reflected prior initiatives towards greater community participation, which was supported by the previous Labour governments and inclination towards neoliberalism marked by cutting down local authorities' spending. This Act aimed to decentralise decision to local governments and local communities, bringing more attention to the locality, while the government centralised power in other aspects, such as infrastructure [103]. The Localism Act has been criticised for little effect on the balance of power between central and local governments, and research explores the possibilities it offers through neighbourhood planning and its impacts on qualities in urban areas and collaborative processes. This Act has a major implication for London's neighbourhoods and how climate interests may be included.

Earlier research on urban regeneration and sustainability has emphasised the significant role of governance forms, organisational frameworks, and allocation of funding in facilitating or restraining development and engagement and impacting the outcomes. Alkhani [75] revealed how a lack of public funding to soil cleaning and construction of affordable housing in an increasingly privatised economy in Copenhagen in the 1990s underpins the City's inclination in this period towards reliance on private investors leading to waste many opportunities for the community and the city. The issue of cuts to local authorities budgets in the UK affecting their powers, and the need to locate more funding sources for climate initiatives are gaining an increasing interest. The IPPR's report mentioned above recommended establishing an Energy Retrofit fund for England with $£ 5.3$ billion per year until 2030 and a mixed strategy for financing housing retrofits increasing government support to half of the cost and the other half from private finance [98].

A major difference between London and Copenhagen lies in the power of their local authorities on development. Copenhagen steers its lands, services, and built environment through a strict planning framework with a Municipal Plan setting out guidelines for development in its areas and frameworks for binding local planning regulations with a tight development control managed by the City. Greater London's Authority's power is limited to drawing up guidelines for future development in conformity with the National Planning Policy Framework but without a binding development framework at the local level. The 32 London boroughs and the City of London individually follow the London Plan through their binding local Development Plans DPDs. Local authorities negotiate individually with different partners, for example, around housing delivery adopting different models. With the lack of necessary funding from the state, this can turn into an unbalanced power relation favouring investors' interest. Future of London Chief Executive Lisa Taylor highlights that one of the major challenges is that 'there is not enough understanding of priorities between public- and private-sector partners' [104]. 
She pointed to London's underused lands and brownfield areas that lack investment as some of the challenges facing London, but at the same time, highlighted their opportunities. In light of the current debate, these sites should be prudently developed to promote sustainable development with good place-making to accommodate people, the ecology, and the economy through urban regeneration. Many deprived neighbourhoods in London can benefit from including climate measures in ecological place-making approaches (UDMW, 2020) [80]. These outcomes can inspire community neighbourhood plans and emphasise the need for integrated, holistic, and strategic approaches.

From a policy and governance standpoint, a study in 2016 by the Danish Centre for Environment and Energy of climate governance in Danish municipalities revealed the importance of political and administrative leadership at the local level for a proactive climate change policy [105]. They stressed the significance of a positive attitude that when the municipal actors introduced climate policy and adaptation measures as policies and efforts with positive effects on other policy areas, they encouraged prioritisation of climate adaptation measures despite their cost or measures that involved potential conflicts around land use. The study revealed that successful cities could understand, benefit from and work towards synergies in both short- and long-term investments, such as the integration of green and blue infrastructure in buildings and the public realm. Conversely, the case studies showed that cross-sectoral land-use conflicts that were not addressed can well pose a barrier to effective climate adaptation.

\subsection{Copenhagen Moving towards Eco-Innovation}

The Planning Act 2007 and the Danish spatial planning guidelines expressed clear aims to support sustainable development in Danish cities, natural and rural areas. Danish Strategy for Sustainable Development 2014 emphasises the active participation of public and private actors in delivering sustainable growth. Focus on sustainable development has shaped Copenhagen's strategies for the past 15 years.

Copenhagen has already witnessed a significant shift during the 2000s from being focused on sustainability in buildings towards more holistic eco-friendly neighbourhoods where the focus in Agenda 21 was expanded from the building scale to a neighbourhood scale, while also addressing partnerships in implementing the Agenda and more inclusive governance with a focus on the role of the public sector and the City as the environmental flagship. At the same time, the City instigated in 2007 a new Sustainable Copenhagen Strategy [59] that aimed to kick off the Municipal Plan 2009 [58] and change the planning process to a one committing to several partnerships and consultation from the beginning across the public, the private sector, and the society. The need to involve the private sector in a collaborative, but controllable way and create the basis for a new knowledge economy was acknowledged. The sustainability principles developed in this strategy included promoting Copenhagen as highly environmentally sustainable, inclusive to all, and economically viable to accommodate the knowledge economy and the growing creative industries. These principles were applied in an Idea Competition for the North Harbour-the former industrial and primary harbour site that the City earmarked as the new Copenhagen Eco-Friendly Neighbourhood aimed to house 40,000 inhabitants and 40,000 jobs and to be developed in phases awaiting the transfer of the remaining harbour activities. The development of this site was to take place following compact city principles, which Copenhagen advocated as a significant prerequisite of sustainability in the plan and as a showcase on how to develop a holistic, eco-friendly neighbourhood. This neighbourhood should demonstrate environmental innovation and Copenhagen's leadership in sustainability, sustainable technology, and climate efforts [65]. The result of the competition was announced and showcased Copenhagen's leading role at the UN Climate Change Conference COP15, which the City hosted in 2009. It is then when the City first launched its carbon-neutral scheme.

This Eco-Friendly Neighbourhood at the North Harbour can be seen as a turning point in the city's approach to sustainability, energy transition, dealing with climate risks and involvement of the private actors. It came as a culmination and a consensus on earlier progress in the energy transition, and efforts 
around transport sustainability and conservation of biodiversity. It was also a search for new flexible urban typologies that could extend the principles of sustainability and address climate. Since the end of the 1990s, Copenhagen has been working on reinforcing environmental concerns in city buildings and the different sectors, hereunder isolation of buildings, and reducing private transportation use, which was identified as a significant source of $\mathrm{CO}_{2}$. The Copenhagen City goal in the mid-2000s was to reach a modal mobility split of one-third by person car, one-third by public transportation, and one-third by cycling [58]. Further, Copenhagen adopted an aware densification strategy around public transportation nodes, imposed a congestion charge, and gave more attention to expanding cycling lanes and networks and introducing 0 -energy zones. This pattern was reinforced with the construction of the four-phased circular metro. With all these initiatives, Copenhagen has been able to achieve a higher level of sustainable mobility and reduce $\mathrm{CO}_{2}$ levels and the city's environmental footprint. Several architectural projects in the city during the 2000s had experimented with some sustainability aspects to manage water and electricity, such as in the Carlsberg Regeneration Site. This is a significant change compared to the 1990s, where the private sector's investments in the harbour areas had been significantly criticised for ignoring the interest of people.

At the occasion of the Eco-Friendly North Harbour competition, and using the competition as an experimental ground to identify suitable assessment criteria to be used in urban projects, the city developed a 'Sustainability Assessment Tool' that was used in assessing the competition [64]. The tool included various measures to promote the Eco-Friendly Neighbourhood concept in concert with the Sustainable Copenhagen Strategy. The tool, an inspiration to local authorities in Denmark, was aimed to become a 'dialogue tool' when negotiating projects with stakeholders, with a clear language about values and standards. The clarity in the relationship and expected outputs between local authorities and investors has shown to be an essential factor in making investment decisions [75]. The competition's assessment emphasised several aspects: The inclusion of renewable energy solutions, managing rising sea levels through landscaping, dealing with blue-green corridors and biodiversity, sustainable transportation, and innovation in waste and water management. Other aspects focused on the flexibility and adaptability of the urban structure and the power of the urban design concept for generating liveability. Following on what has been implemented so far, the private actors have been enthusiastic regarding experimentation with new energy sources as in the Copenhagen International School completed by the firm CF Møller with the world-largest solar panel facades, incorporating 12,000 panels. They have been engaged in showcasing their goodwill in this visible site. Visibility was an effective strategy that the city used to incentivise the private sector. This paralleled developing a labeling system and showcasing innovative contributions in the city debate platform on architecture Copenhagen $X$. Although some criticism was directed towards the development being focusing interests at the centre city, this strategy succeeded in initiating a broad consensus on sustainable solutions.

The implementation of the winning entry, which was one of the youngest planning firms is managed after a pre-qualification process through the local planning process, which is the legally binding framework for the investors committing to sustainability requirements. It took place in phases with the first phase designed in detail and comprising all the Inner North Harbour. The first phase is close to being built based on an area local plan [63], ensuring that envisaged plan aspects and functions are included. This is a positive approach compared to the dominating piecemeal development in the 1990s.

Despite the original aims to promote the North Harbour as an inclusive, sustainable neighbourhood, it was first in 2015 when the Copenhagen City Council adopted social housing delivery in the North Harbour within a broader city agreement with one of the housing associations to meet delivery gaps. As a result, almost 100 affordable residential units have been delivered so far. This reveals the challenge of managing inclusiveness when urban areas acquire a higher value due to adaptations and invites to assess sustainability actions and collaborations in other city areas.

The development of the North Harbour has paved the way to a large-scale new plan for 35,000 inhabitants comprising another island, Lynetteholmen, in the extension of Copenhagen Treatment 
Plant's island with leading consultancies involved in the assessment of climate implications and EIA. However, the plan, which involves significant construction works and filling in the harbour, is suspected of creating an exclusive neighbourhood due to its cost and prompt tension between the centre city and the periphery, highlighting the importance that all interests should be balanced in the sustainable city.

For decades, Copenhagen used the local planning process to include binding regulations and requirements related to the different sectors and to implement its municipal plans, which are being reviewed and updated every four years. Copenhagen uses local planning as a useful tool to ensure that environmental impacts are appropriately managed since local planning for major development projects that may have various potential impacts involve compulsory EIA and assessment of impacts on sustainability. They should be developed in conformity with the city plan.

It is important to note that local planning does not stipulate adaptations to be made in the existing building mass but has only a forward-looking impact on any future development that requires a new local plan, including major adjustment applications. Further, the local planning process is not a guarantee for promoting broad neighbourhood interest as local planning can be carried out for individual small-scale properties. Therefore, visions for sustainable development encompassing broader urban areas or neighbourhoods are essential. This requires an in-depth understanding of decision-making and the circumstances in which these holistic plans are being launched in the city.

The implementation of innovative sustainability principles in the broader built mass in Copenhagen and on a neighbourhood scale needs to be assessed. It is possible in this connection to trace the involvement of the private sector in terms of developers using the Danish planning database Plandata to which all plans are reported.

\subsection{North Harbour Innovation Hub}

Several industries were involved in innovation in the framework of the ambitious four-year live project Energy Lab Nordhavn. The project was implemented in 2015-2019 to experiment and develop recommendations to politicians and other organisations on sustainable and flexible energy systems and transition solutions [106]. The project brought together several Danish engineering practices, including among others Danfoss, Nerve Smart Systems, COWI, ABB, Metro Therm, with the city energy company HOFOR, the City of Copenhagen, BY \& Havn organisation and researchers from Denmark Technical University DTU. As a result, HOFOR could reduce district heating, and in consequence, $\mathrm{CO}_{2}$. A new intelligent, warm pump was developed to provide the cruise terminals with green heat. More renewable energy technologies were developed and included in the heating system, ensuring flexibility in the energy network. These initiatives, which were supported by the public subsidy scheme The Energy Technology Development and Demonstration Program (EUDP), point to the importance of developing a system for assessing and sharing the private sector's contribution to innovation and, consequently, climate adaptation and mitigation.

\subsection{Copenhagen Managing Flood Risk}

Copenhagen is at risk of an intense downpour. Copenhagen Climate Adaptation Plan of 2011 [60] highlighted that in 2010 this caused damage equal to about $£ 850$ million. In this plan, which followed on COP15, the City of Copenhagen followed consciously upon the recommendations of the UN's Intergovernmental Panel on Climate Change with regards to managing flood risks. This plan expected an area of 48 hectares to be flooded in 2060, and 595 hectares in 100 years and assessed the economic risk from stormwater at $£ 69$ million a year in 2060 .

On this basis, the plan recommended SUDS to be implemented to manage stormwater locally, disconnecting them from the sewer system to bring a significant impact, since stormwater from roads and roofs establishes two-thirds of the total wastewater in Copenhagen. Through this method, it is possible to store water and treat it before discharging it to other surface water bodies using green technology and contributing to a greener city in the form of rain gardens, canals, lakes, etc. 
This approach is widely acknowledged by research and practice in many cities, hereunder the Blue-Green Cities programme as able to contribute to the public realm and the 'urban park' concept, leading to reducing $\mathrm{CO}_{2}$ [82]. Another method identified is leading surplus stormwater to surface spaces, including backwater valves, and gutters-the so-called plan B. Within this understanding, all basements in the city where flooding is noticed should be protected. However, this relies on private initiatives, as the city's role is only advisory, and this is not yet financed through Tariff funds as it was not yet contained in the service objectives for the supply company [60]. Copenhagen Adaptation Plan stipulated that new sewer systems have to be designed in suitable dimensions to cope with the new volumes of rains, and SUDS solutions to be promoted and included in all relevant municipal plans. The plan instigated a clear strategy at all levels, from the building to the region with varying degrees of action to reduce the probability, scale of the impact, and vulnerability. It pointed to the opportunities related to activating 'schoolyards, institutions, large car parks, courtyards, allotment gardens, road expropriations, and gardens' in the existing city to contribute to climate-adaptation. Building green roofs and green walls, planting trees along roads, and creating connected green networks were other measures recommended by the plan [60]. The city has recently included these aspects in its adopted Municipal Plan 2019 titled [Global City with Responsibility], published in April 2020 [57]. This demonstrates that climate mitigation and adaptation are acquiring a significant interface with the built environment and people's and institutions' every day, which would increase city resilience and sustainability.

Adaptation Plans' recommendations have been taken further in the Copenhagen policy, including the Cloud Burst Management Plan, which was coordinated with Copenhagen Energy and neighbouring authorities [61]. This plan aims to coordinate the pluvial flooding projects with ongoing urban development projects all over the city, which involves adaptation in road networks. Financing was expected as a combination of public and private investment to be implemented by the City, Copenhagen Energy, and the private homeowners through taxes and income from related charges-these are drainage charges included in the price of each $\mathrm{m}^{3}$ of water bought from the Water Company. Some legal measures around implementation were to be clarified, for example, how much the company should finance adaptation measures. Recreational solutions are to be financed by municipal tax revenues in addition to revenue from charges. While the city administration is responsible for providing the legal framework, the utility company is responsible for ensuring that drainage systems meet the required service level, and property owners are responsible for flood-proofing their properties on private land. Although this plan is not binding, it draws up practical guidelines to be included in the municipal, neighbourhood, and the binding local plans.

The plan involves 300 projects over the next two decades at the cost of DKK 3.8 billion, and some pilot projects have already been implemented. It is important to assess the involvement of the private actors in the Copenhagen Cloudburst Management Plan's implementation, addressing strategies and proposals at all levels.

On the other hand, Copenhagen has been working on meeting the challenge of rising sea levels. This aspect has been globally acknowledged as being a result of melting ice sheets and glaciers and the increase in the global temperature resulting from the accumulation of greenhouse gases [107]. Due to its location by the sea, Copenhagen is subjected to the risk of storm surge and, as a result, floods, causing damage to properties and impacting on investment, health, and society. The Danish Metrological Institute has estimated the sea around Copenhagen to rise by $1 \mathrm{~m}$ during the coming 100 years, which is a significant increase given the flat topography of the city. It alarmed that high water increase will happen more often in the future, hitting $180 \mathrm{~cm}$ each 20-years in 2060. As a follow-up, The Copenhagen Adaptation Plan elaborated on an assessment of required defence measures and technologies, and their economic and environmental sustainability and impacts on urban life and recreational areas and how to implement them through the regulatory planning system. An estimate of DKK 2.3 billion in construction cost was highlighted to protect the city to high water of $255 \mathrm{~cm}$ above the average level [60]. Ideally, this should be enforced through the municipal and local plans 
through ensuring to establish raised edges along the inner part of Copenhagen Harbour and the coast. Another alternative option identified is to establish a barrier at the North Harbour and the coastal area Kalveboderne and elevate the coastline to The Sound. The Climate Adaptation Plan saw this as a more desirable solution for architectural and recreational reasons. In areas outside the barriers, the local protection of buildings against flooding, necessary installations, and appropriate land use designation should be ensured.

In practice, the City Council of Copenhagen is the party that makes decisions on establishing coastal protection under the Coastal Protection Act. However, it is landowners themselves who must contribute to the financing and the implementation in compliance with local planning.

At the North Harbour-the largest development site in the city-the Metro Company is the party that will implement both the last phase of the North Harbour Metro and most of nature and recreational areas at the outer North Harbour. Allowing this required legal changes in 2011, 2018 and 2019, including the law of the two companies; the Metro Company and the Development Company By \& Havn (the latter manages the harbour and is a landowner facilitating investments). Simultaneously, the land use of the area was changed in the municipal plan from harbour to institutional and recreative use. This mechanism demonstrates how Copenhagen implements its policies through continuous adjustments. The question is how to implement the desired ideas in areas of less interest and what role the private actors would have.

The Municipal Plan 2019 includes several strategies to help Copenhagen become CO2 neutral already in 2025 targeting both the energy performance, less pollution, and more green growth through the following:

- Continue efforts to phase out fossil energy through biomass, develop district heating, adopt renewable energy technologies, and alternative energy sources such as solar cells, geothermal, wind turbines, and heat pumps.

- Ensure energy optimisation at the city level by using low-temperature district heating and heat storage and establishing remote cooling.

- Reduce energy consumption in buildings, increase energy efficiency, and continue improvement in construction and operation of buildings, industrial plants, and infrastructure.

- Integrate climate adaptation with urban development, urban adaptation, and regeneration, including opportunities for innovation and green growth. Here the plan stipulates that all existing and new green areas should have the quality to contribute to a green city to benefit citizens, biodiversity, and the climate. Like in the London Plan, more green roofs are envisaged to support rainwater management, $\mathrm{CO}_{2}$ absorption, urban farming, and social arrangements. The plan envisages that 100,000 new trees should be planted before the end of 2025. The tree-planting project has been in focus for some years now, with the city dedicating a budget in 2015 of $£ 360,000$ to planting trees within a larger urban forest project in the centre city to improve air quality.

- In terms of stormwater, it stipulates the establishment of efficient rainwater management infrastructure leading water to the sea and to use the city Storm Flood Plan as a background to develop technical solutions.

- Work towards a waste-free city where all waste is recycled.

Copenhagen demonstrates great engagement with the climate goals, and some examples close to the waterfront demonstrate Copenhagen's commitment and the private sector's enthusiasm.

The Climate-Resilient Neighbourhood strategy for the Copenhagen's St. Kjelds' neighbourhood also demonstrates how climate change adaptation measures can be included in a residential neighbourhood plan to increase resilience, but with needed upfront efforts by the city [62]. The model demonstrates collaboration forms, where the city and its energy company HOFOR and the City Integrated Renewal Company go upfront and involve public participation and smaller-scale private investments, for example, in green roofs and rain gardens. 
Copenhagen's ambitions call to assess the private actors' contribution in more complex city areas and city fringes where interest is less evident and how much these measures will be actively used in holistic perspectives to promote sustainability in all terms.

\subsection{The Role of Climate Finances}

The delivery of climate goals calls to generally explore the impact of climate finances on the private sector's commitment. Green finances are an essential tool of Danish Climate strategies. According to Statistics Denmark, in a report on green national accounting in 2018, Danish industries spent a total of DKK 3.4 billion in environmental protection in 2016 - an increase by $8 \%$ compared to 2015-against DKK 29 billion spent by the public sector [108]. They generated over DKK 34 billion in national green taxes in 2017, of which over 50\% are energy taxes [108]. Danish industries benefit from the State's commitment to supporting the energy transition. In the same year, DKK 8.7 billion were given in support of Danish industries, including in Copenhagen, to support renewable energies. According to OECD Environmental Performance Reviews, this significant investment places Denmark in a leadership position in the OECD area [109]. One of the important gaps is that there is no relationship between the size of the green taxes and the size of the environmental impacts. It is generally important to make businesses aware of the economic cost related to their climate footprint. The engineering company COWI in collaboration with other businesses and the universities, has been developing tools to support the industries in calculating an accurate price on their resource consumption, hereunder associated with the production of some goods, establishing the so-called Natural Capital Accounts (NCAs). This will prompt them to work towards reducing the environmental footprint [110].

As a summary, Copenhagen's private sector, in terms of landowners and developers, is generally committed through the local planning process, environmental assessments, and payments to the different relevant services related to environmental and climate adaptations and green taxes. The private sector also benefits from state support to renewable energies. On a broader city level, it succeeded the city in the past decade to involve the private sector in terms of investors, developers, and consultants in sustainable projects and climate innovation through a city-developed sustainability framework. The private sector has been acquiring a more positive role than the 1990s within a systematic governmental approach and city leadership. This also comes as a result of a growing synergy between different stakeholders' interests resulting in new collaborations around urban development. The private sector's involvement has been significant in the North Harbour within more holistic and innovative frameworks and with the public sector going upfront with infrastructure, funding innovation, and incentivising visibility of technological and plan innovation in this image-branded site. It remains crucial to explore the impact of this project on prompting similar initiatives and collaborations in other city areas where interest is less evident.

\subsection{London-Gaps between Goals and Action}

While the climate response has increasingly become systematic in Copenhagen and targets implementing the climate goals through robust adaptation plans, strong municipal policy framework, and flagship branding projects, the situation in London has been different as the synergy in climate initiatives, and the extent to which they create a clear framework is less clear.

\subsection{Planning and Sustainability on the Ground}

In its statement Achieving Sustainable Development, the National Planning Policy Framework of 2012, 2016 and 2019 [17-19] clearly stipulate that the purpose of the planning system is to contribute to sustainable development. The NPPF 2019 sees this in supporting vibrant, safe, and healthy communities with diverse housing offers and well-designed urban environments, contributing to building a responsive and competitive economy and protecting and enhancing the natural, built, and historical environment. The plan stipulates that effective land use should be made, and planning should improve biodiversity while minimising waste and pollution and using natural resources 
prudently. It states its aims for a low-carbon economy and mitigating and adapting to climate change. However, the plan states that these are only guiding objectives and are not 'criteria against which every decision can or should be judged' [19]. While these planning frameworks should guide development to deliver sustainability, the interpretation is left to local authorities based on their understanding of the local context.

London Plan 2016 has elaborated on these principles and included them in its guidelines. However, the implementation is not wholly in the hands of the Mayor of London but in the authority of the 32 London boroughs and the City of London who declared aims for sustainable development and meeting climate challenges in their core strategies, such as London Borough of Hackney, London Borough of Lambeth and others. The complex sustainability goals call for holistic and more integrated approaches that often lack, especially with cuts in local governments' budgets and health and education finances. Several neighbourhoods in London suffer from deprivation, and regeneration has often been criticised for focusing on the rich and initiating gentrification leading to displaced residents and reinforcing social segregation. The public debate is much critical to a shortage of affordable housing delivery, especially with the significant increase in estate prices in London [111]. This includes boroughs that have declared aims towards sustainability as Hackney. Neighbourhood planning, which is supposed to communicate local communities' interests and facilitate inclusive initiatives in the public realm, also faces many obstacles, and only a few have been established in London so far. In this context, where the public authority is no longer taking the lead on meeting social and environmental needs, would the private sector fill the climate gaps? Also, how can more of the private sector's engagement be promoted?

Exploring two recent London regeneration projects, the VNEB (Vauxhall, Nine Elms, and Battersea) Regeneration project in central London and Barking Riverside, and their compliance with London and local plans' sustainability and climate ambitions reveals a few issues. Although the Vauxhall Supplementary Planning Document (SPD) adopted in 2013 stipulates that the project should fulfil ambitious sustainability requirements in compliance with the London Plan [35], the requirements are not sufficiently explicit in terms of obligation and standard. It is unclear to what degree they can hold the developers accountable, although they require a BREEAM Excellent. The Battersea Power Station Regeneration Project aiming to accommodate 20,000 people and led by a consortium of international Malaysian-based investors complies with decentralised energy; however, the project is entirely dependent on gas to power Combined Heat and Power Engines (CHP) [112]. Despite more energy efficiency, the project does not live up to the ambition to promote renewable energy. While the project has a good focus on biodiversity through green roofs and parks and an innovative social focus in many aspects, it could have been more ambitious with regards to climate adaptation and mitigation. Moreover, it ends by cutting down on affordable homes, which were already reduced following negotiations with the Wandsworth Council from $40 \%$ to $15 \%$. This demonstrates the challenge facing this type of project and the importance of the local authority being firmer.

The Development of the Barking Riverside London includes a much more explicit focus on climate through its holistic landscape strategy that addresses flood risk and stormwater [113]. The project aims to develop a brownfield site formerly occupied by Barking Power Station into a mixed-use plan, with over 10,000 homes within the Thames Gateway Redevelopment Zone. The project aims to be based on district heating and has a high focus on biodiversity. Fifty percent of the homes are to be delivered as social housing. One of the project's primary pillars is the support it receives from the Mayor of London. The project is a partnership formed in 2016 between the Mayor of London and the residential developer L \& Q, and with the NHS's involvement to support the project as an example of a healthy city.

There are still unlimited assets in London's global city in terms of economic, social, and cultural diversities and knowledge opportunities and many underused land potentials. The question is whether climate mitigation and adaptation would be another burden or an opportunity to be actively used in more ecological place-making. Such an approach would deliver sustainability goals, improve localities, 
and contribute to health and wellbeing, benefiting nature, and climate goals. Such approaches would also contribute to the creation of more jobs that need various skills. What is the role of private actors? How to incentivise them and engage them in more sustainable place-making?

\subsection{Climate Policy Framework}

With the Climate Change Act 2008 [23], the Government committed to reducing the UK's greenhouse gas emissions by $80 \%$ by 2050 and identified a climate budget towards this goal. All new developments should fully contribute towards this target following the principle: (1) Be lean: use less energy. (2) Be clean: supply energy efficiently. (3) Be green: use renewable energy.

The Greater London Authority Act of 2007 gave the Mayor a new statutory duty to contribute towards the mitigation of and adaptation to climate change in the UK by addressing London's emissions amounting to over 44 million tonnes in 2015 [32,33]. This has been a challenging target for the Mayor, who expressed aims to promote London as a world leader in tackling climate change. Climate mitigation and adaptations continued to be major issues in the London Plan 2016 informed by the UK Climate Projections 2009 (UKCP09). Based on these, the London Plan 2016 [30] (p. 177) anticipated that by the 2050s, London would witness an increase in mean summer temperature of 2.7 degrees, and increase in winter rainfall by $15 \%$, and a decrease in mean summer rainfall of $18 \%$. This means some areas will suffer the heat island effect while others will be flooded. The plan included specific measures for climate adaptation and mitigation addressing stormwater and reduction of $\mathrm{CO}_{2}$ in the built mass through the encouragement of decentralised energy systems, including the use of low carbon and renewable energy and energy generated from waste.

The Mayor's Climate Change Mitigation and Energy Strategy of 2011 contains further proposals involving reducing the energy consumption of London's existing building mass-much of it is very old and have very poor isolation-and decarbonising London's energy supply with an acknowledgment of the importance of shifting towards zero-emission transport sector in London. Emissions from transport are a main challenge in London's climate accounts and nationally [114]. These aspects underpin the 2016 London Plan's ambition to achieve an overall reduction in London's carbon dioxide emissions of $60 \%$ below 1990 by 2025 [30]. However, this is only a framework that GLA expects to monitor and work on with other London local authorities expected to develop their detailed policies, with no binding regulations.

The London Plan 2016 emphasises the importance of reducing the environmental impact of existing urban areas through policies and programmes to bring existing buildings up to the Mayor's standards on sustainable design and construction and direct the boroughs to develop policies and proposals to retrofit existing buildings sustainably to reduce carbon dioxide emissions. Here the plan points to retrofitting energy efficiency measures, promoting decentralised energy, and renewable energy opportunities.

For new development, the plan stipulates that major development proposals should include a detailed energy assessment to demonstrate how carbon dioxide reduction targets are reduced. They should present energy-efficient design, and further reductions through on-site and decentralised energy systems (and cooling and combined heat and power). The plan also expresses awareness of the necessity of including details of unregulated emissions considering the buildings in use and green management. The plan stipulates that the highest standards of sustainable design and construction should be achieved in London, considering both construction and operation, efficient use of natural resources, sustainable procurement of materials, using local supplies, and protecting biodiversity [30] (p. 184).

The importance of promoting decentralised energy regarding the general gas and electricity supply is emphasised to achieve $25 \%$ of the heat and power used in London being generated through the use of localised, decentralised energy systems by 2025 [30] (p. 188). To implement this, the plan stipulates that the London boroughs should take this further through their LDFs and cooperate across boundaries (including outside Greater London where appropriate) to identify and address potential capacity 
shortage on the broader energy network serving their area. To ensure response, the local authorities are required to develop energy masterplans and developers to prioritise connection to existing or planned decentralised energy networks where feasible and to engage with relevant boroughs and energy companies at early stages [30] (p. 189).

In terms of climate adaptation, the plan includes a focus on innovative technologies and encourages the boroughs to experiment with new technologies to reduce the use of fossil fuels and carbon dioxide emissions, for example, through the uptake of electric and hydrogen fuel cell vehicles.

Urban greening in the public realm and integration of green infrastructure in all development proposals were emphasised to increase the surface area greened in the Central Activities Zone by at least five percent by 2030, and a further five percent by 2050. The boroughs should identify where to include green infrastructure in terms of planting, green roofs, and walls and soft landscaping to mitigate the effects of climate change, hereunder the urban heat island. The ambition is to plant 2 million trees in London by 2025 within the urban park concept.

These are all ambitious guidelines that, in the absence of clear regulations and standards would be difficult to implement, or at least, would be subject to different interpretations by the different local authorities. For example, building regulations concerning the adaptation of the existing urban mass, energy efficiency in line with carbon targets and environmental impact assessments need to be upgraded to match policy ambitions. For private investors, the policy guidelines suggest major changes and ambiguities that would be difficult to take on board and assess their impact on investment.

\subsection{Flood Risk Management}

As a result of climate change, the London Plan 2016 expects that fluvial flood risk would grow in all London's rivers with predictions of increases in peak flows of up to $40 \%$. Approximately $15 \%$ of London is already within a recognised flood risk zone from either tidal or fluvial flooding [30] (p. 200). Therefore, the plan stipulates that all planning and development should comply with the flood risk assessment and management requirements set out in the NPPF and the associated technical guidance on flood risk, and with measures and regulations proposed in the Environment Agency's Thames Estuary 2100 (TE2100) Plan up to 2100, and Catchment Flood Management Plans. Strategic Flood Risk Assessments are to be conducted by boroughs to determine future efforts, policies, and actions to reduce risks.

The Thames Estuary 2100's primary focus is on maintenance, refurbishment, and continuous improvements to the current defences and raising of river walls at some locations [35]. This plan stipulates that major adaptation is not due before 2070. Meanwhile, the analysis of stormwater impacts points to the increased risk of Thames River pollution due to sewage overflow into the river under heavy rain.

The Thames Catchment Flood Management Plan 2009, developed by the Environmental Agency, identified the nature of risks and how to manage them [28]. This plan recommended that every new development should provide measures to reduce flood risks, for example, by including flood storage and, in principle, avoid development in risky areas. On this base, the London Plan 2016 stipulated that development should use SUDS methods, including green walls, to ensure that surface water run-off is managed, close to the source following drainage hierarchy, and promote efficient water use, recreation, and biodiversity: (1) Store rainwater for later use; (2) use infiltration techniques, such as porous surfaces; (3) direct and collect rainwater in ponds or open water features, and other techniques before allowing minimum remaining rainwater to the combined sewer. Consequently, regulations need to be updated to enforce restrictions in permitted development rights for impermeable surfaces, and the boroughs should identify areas with the need for surface water management in line with Flood and Water Management Act 2010.

This review of The London Plan's guidelines demonstrates that it has addressed important aspects of adaptation and mitigation and followed recommended techniques in climate research. However, the plan's influence is limited to policies and guidelines, which leaves space for different interpretations 
by the boroughs and ambiguities for the private developers. Ambiguity can also result from the lack of concrete plans and dialogue tools that can help agree on processes and outcomes and acknowledge mutual benefit. Here appears the need to have holistic, innovative, and sector integrated planning frameworks that integrate climate measures in specific urban areas, integrate/bridge between local plans and neighbourhood plans-the latter were introduced by an Act in 2017, and forge opportunities for new collaborations between local communities and other public and private actors. Encouraging win-win insurgent solutions can be strategically useful. The University of Westminster's Master students' works addressing the old Naval Dockyard Deptford neighbourhood on the River Thames in the Lewisham and Greenwich boroughs reveal the multiple opportunities that can be created as a result of more holistic public realm strategies. These strategies can elaborate on ecological and cultural place-making, ensuring continuity in ecological initiatives and benefiting all parties, including new and existing residents. They show the benefits of interacting with the local communities to learn about their needs and discuss how best these measures, such as NBS, can be part of the neighbourhood's thriving future.

\subsection{Knowledge-Base on Gaps, Guidance, and Assessments}

In the absence of an overarching organisation taking the lead on coordinating implementation overall in London, it is evident that knowledge organisations play a significant role in the current governance landscape bringing together different actors who otherwise would not have worked directly together.

The London Climate Change Partnership (LCCP) is a knowledge centre on climate change adaptation involving public and private organisations and community NGOs, including the City of London, GLA, Environment Agency, the UK Green Building Council (UKGBC), Thames Estuary, and academic organisations. Its role is in collecting and sharing information, informing policies and driving change through member organisations and exchanging experience of adaptations. They look as well at how investment can be attracted and how related jobs can be created. This is also very important as one of the benefits of climate efforts is its contribution to local economies. LCCP [115] acknowledges the current lack of systematic data collection describing climate change impacts and whether adaptation actions are effective. Therefore, it works on identifying climate indicators and addressing knowledge gaps to support London's preparedness to climate change and help London boroughs, the private sector, and service providers [115]. LCCP draws attention to the difficulty of drawing reliable conclusions about adaptation from data, and the importance of relating action to impact and the need to collect data over a reasonable length of time to determine trends in an uncertain future [115].

The UK Green Building Council (UKGBC) is another charity organisation launched by the construction and property industry in 2007 with over 400 member organisations that work as a catalyst for sustainability across the industry, and by its own aims 'established to offer clarity, cohesion, and leadership to a disparate sector, and campaign for a sustainable built environment.' [116]. The organisation works in advocacy, research and innovation education and policy. It has since been greatly influential and succeeded in gathering leaders from across the built environment. UKGBC has been active in supporting the UK's transition to implement the Paris Agreement under the umbrella of the World GBC. UKGBC launched its Advancing Net Zero Programme in 2018 to support the UK property and construction sector's transition and published its Net Zero Carbon Framework in 2019 [117]. This came in the footsteps of the WorldGBC global Advancing Net Zero campaign to shift to $100 \%$ net zero carbon buildings by 2050 .

UKGBC launched a two-year programme funded by the John Ellerman Foundation on the benefit of Nature-Based Solutions (NBS) in urban areas for more climate resilience and how to increase the application of these solutions targeting developers, owners, and occupiers of buildings and infrastructure in urban areas [118]. Several stakeholders reinforce this research, including developers, owners, environmental NGOs, academia, and professional bodies. UKGBC is also developing research 
with multiple stakeholders on the circular economy and biodiversity. Accelerator Cities [119] is another programme by this organisation, bringing together several local authorities to analyse what support they need to take more significant action on home retrofit. The first steps stressed the need to support local authorities' actions to enable a holistic approach at the city level. The programme explores and develops funding propositions in partnership with the finance sector.

The importance of developing tools and indicators to assess environmental performance in buildings in the UK was behind the launch of the BREEAM assessment method by the Building Research Establishment as part of The International Code for a Sustainable Built Environment. It has been broadly used in the UK to assess buildings, master plans, and infrastructure projects with over 500,000 certified developments. The UK Government's Construction Strategy stipulates that all public projects should carry out this assessment. Local authorities may require a BREEAM assessment as part of their local plan or as a specific planning requirement for individual development projects. This means it is only a selective procedure and does not give the right picture of the situation. Besides, criticism highlights that it is mostly used as a tick box for companies who search to finish with minimum requirements. Two assessments are carried out in this framework; one at the design stage and another after construction. However, the assessment looks at technical issues and operational matters without considering the entire circularity of the building. There are no current and systematic requirements in the broad building mass to assess sustainability and report it. Although the BREEAM focuses on assessment across different categories, its potential on the urban scale is limited compared with the sustainability tool that Copenhagen developed. The Copenhagen Sustainability tool is more capable of creating synergy with the city's overall aims, not only in terms of environmental performance but also in terms of planning approach, synergies, and sustainable city outcomes.

As a reaction to the lack of clear guidance on sustainable design solutions to reach a sound and rapid energy reduction and a zero-carbon future, a voluntary network London Energy Transformation Initiative (LETI) was created in London in 2017 supported by GLA and local authorities. It was formed to contribute evidence-based recommendations for two primary policy documents; the new London Environment Strategy and the London Plan [120]. This network gathers over 1000 built environment professionals, including planners, developers, contractors, engineers, architects, housing associations, academics, sustainability professionals, and facilities managers. LETI highlights its aims to prompt policy change and ensure a suitable and updated regulatory framework since Building Regulations use outdated carbon emission factors unable to prompt a targeted climate path [120]. Among LETI's principal recommendations to London Plan and Energy Assessment Guidance is to consider total life cycle carbon emissions through a national level whole life cycle carbon assessment to create unity in assessment indicators and methods. This is not part of the current building regulations. Whole-life carbon includes operational and embodied carbon.

LETI identifies a new building with net-zero operational carbon as one 'that does not burn fossil fuels, is $100 \%$ powered by renewable energy, and achieves a level of energy performance in-use in line with national climate change targets' [38]. Dealing technically with operational carbon aspect would differ between small scale residential development and other building typologies that require additional renewable energy provision off-site.

An emphasis is placed on circularity, which is not included as a measure in current building regulations: 'A building that is whole life net-zero carbon meets the operational zero carbon balance and is $100 \%$ circular, this means that $100 \%$ of its materials and products are made up of re-used materials and that $100 \%$ of its materials and products can be re-used in future buildings.' Construction, transport, and disassembly will be carried out with renewable energy leading to zero carbon emissions associated with the embodied carbon.

LETI recommended to include a calculation of unregulated energy consumption and that all actors should report in transparency on all involved cost in $\mathrm{CO}_{2}$ reduction, including the cost to occupants if heating and hot water are to be provided by heat pumps. The organisation developed a Climate Emergency Design Guide in 2020 with recommendations on design and management processes and 
technologies that can be embedded in buildings to contribute to a zero-carbon city [38]. To make the recommendations practical, LETI focused on four-building typologies and demonstrated the actions required to meet The Royal Institute of British Architects's (RIBA) requirements at each stage. This commitment necessitates to improve the skills of all involved parties throughout the design and of the contractors and service managers.

As a supplement to these Design Guidelines, LETI published an other report in 2020 on Embedded Carbon acknowledging 'a current lack of knowledge in the built environment industry surrounding embodied carbon reduction strategies and calculations' [39]. Both guides are meant to evolve to reflect the change in technologies, carbon budgets, and possibilities within the industry.

These different leading instances in London/UK have joined efforts in a collaboration between LETI, UKGBC, the Better Buildings Partnership, the Good Homes Alliance (GHA), the Royal Institute of British Architects (RIBA), and the Chartered Institution of Building Services Engineers (CIBSE) around a unified paper with 10 critical requirements for new buildings aiming to reach net-zero carbon [121]. This came as a result of consultation across the industry. Building on this paper, LETI published its abovementioned two guiding documents. The key features of the one paper include standards for low energy use for buildings, incite to report on annual energy use and renewable energy generation, call to reduce construction impacts, encourage low carbon energy supply, and lead annual carbon balance calculations.

A webinar organised by LETI in June 2020, gathering leading organisations involved in London's climate response, discussed the built environment contribution to Paris Agreement. It revealed essential gaps in knowledge/data and methodologies regarding the reduction of $\mathrm{CO}_{2}$ in buildings essential to bridge the climate gap. This includes the need for clear building frameworks to assess building performance to reach the London goal being Net Zero Carbon in 2030 for all new buildings. Several key issues were highlighted as essential conditions to assess how close London is to its target: The importance of assessing buildings on the entire life cycle, agreeing on how to report on Net Zero Carbon activity, sharing data among all involved parties and disclosing it in public [122]. The debate acknowledged the significant challenges facing the adaptation of the actual mass/retrofitting since the performance of housing in London had not been improved. It called to identify methods to raise the energy performance of the building mass and required skills. The panelists agreed that a future framework should also look at reductions in different sectors and consider this from an asset and organisational standpoint. A final significant gap relates to the fact that there are many tools in the market developed by different companies making it hard to ensure standards and synergies. A good outcome is acknowledging the importance of a holistic framework used across London and to standardise methods.

While we should look positively at ongoing collaborations and networks among the participant organisations, it reveals how ambiguous the situation is for investment and the urgent need to closing gaps that appear to have multiple layers.

\subsection{Large-Scale Initiatives-Do They Point to the Same Direction?}

While we discuss policy approaches, The Thames Tideway super sewer/tunnel—UK's largest water infrastructure project has been under construction since 2015. This $25-\mathrm{km}-\mathrm{long}$ tunnel, at an estimated cost of $£ 5$ billion, aims to cut the Thames River pollution, especially with heavy rains, reducing CSO overflows into the river and collecting sewage and leading it to Beckton for treatment. Currently, raw sewage flows directly into the Thames River when it rains, and in heavy rain, the situation gets worse in the river, and existing estates and the public realm risk to be flooded. While policy frameworks recommended incremental adaptation, Tideway is a large-scale infrastructure project that will collect overflow from around 34 points along the river and includes public realm features at seven locations, including floatable spaces at high tide.

The tunnel was subject to bids from joint venture private consortia with support from the UK government to reduce risks. The UK Government saw this financing model as able to achieve better 
outcomes than financing the project as solely a public sector scheme [123]. The project is managed by Bazalgette Tunnel Limited, which finances and builds the tunnel and is responsible for its maintenance and operation. The company is owned by a consortium of investors and is supported by HM Treasury's National Infrastructure Plan [124]. The investors manage pension funds for over 2 million UK pensioners and collect funds from customers' bills, which makes the project a clear and tangible investment. Several joint venture companies share the construction along the river. After completion of the work, Thames Water will operate the tunnel as part of the sewage network. The project draws criticism of its environmental impacts during the transfer of construction material and construction and for not being part of a holistic solution for rainwater, such as dealing with green infrastructure and soil permeability [125].

\subsection{What Role for Climate Finances?}

Climate finances also play a major role in climate efforts in London. On the national level in general, the government has set up the Green Growth Fund dedicating $£ 40$ million to support green start-up companies across the UK. Other national budgets fund the low-carbon industry and low heat recovery. In turn, the industries pay a Climate Change Levy contributing to public funding. In London, GLA's green funding sources have included earlier contributions from Urban Development Funds to support public and private projects, hereunder London Green Fund [126,127], which was established in 2009 by the Mayor of London and the European Commissioner for Regional Policy under the Joint European Support for Sustainable Investment in City Areas (JESSICA) Programme. The Fund contributed $£ 120$ million to urban projects in London, including $£ 10$ million from private funding at the project level [126]. Other funds also contributed limited amounts, including the Energy Efficiency Fund, Greener Social Housing, and Biogas. Several regeneration projects in London benefited from the Mayor's Good Growth Fund. The Mayor's funds also include Greener City Fund, which dedicates $£ 12$ million to support the National Park City Concept, and some other green space and planting grants, which have secured support to 79 small-scale community projects in 2019-2020. In general, there is a greater reliance in the UK on the private sector to fill the climate gap than in Denmark. The Committee on Climate Change (CCC) expected that $90 \%$ of green investment should come from private sector funding to meet the UK's yearly Carbon budget [128]. In light of local authorities' budget cuts and the current climate emergency expressed in several London boroughs' websites, for example, Hackney, there is a great need to explore the impact of all funding sources on implementing climate intentions and on the involvement of the private sector. It is also pertinent to assess current and future funding in light of current climate ambitions and the need to close climate gaps on the local and the Greater London level.

In summary, through its different forms of involvement, the private sector has an important role to play in London's efforts to meet climate challenges and close the climate gaps. While sustainability and climate change policies at the government and city level have been evolving, there is a clear need to strengthen the planning and legal frameworks, building regulations, and local planning requirements, and to develop new collaborations to ensure meaningful implementation of policies and the involvement of the private sector at the local level. More holistic and strategic visions encompassing larger urban areas seem to be important to implement urban adaptation measures. Within the current discretionary planning system, the private parties will not optimally contribute to filling the climate gaps. City leadership is a key and, especially in this time of climate emergency, City leadership can offer both clarity to investors and promote the visibility of projects and initiatives to incentivise the private actors. Here climate finances offer several options to increase the commitment of the private sector [41]. Collecting reliable data on the impact on climate through the lifecycle of projects seems very important. 


\section{Discussion and Lessons from the Two Cities}

London and Copenhagen have committed to reducing climate emissions since the emission peak in the 2000s through more use of renewable energy sources and measures and regulations around sustainability and climate in the built environment. The transport sector remains a challenge in both cities. Copenhagen succeeded in reducing its $\mathrm{CO}_{2}$ emissions per capita below London's level in recent years, which can be attributed to more strict frameworks and legislation around sustainability and climate. However, both cities still need to work effectively to reach their targets while providing suitable frameworks for private-sector involvement. The paper has reviewed variations of private-sector engagement in sustainable urban development and climate efforts and frameworks for its involvement in climate mitigation and adaptation in both cities. The discussion has identified differences in legislative and governance frameworks and engagement processes between the two cities. It also identified gaps in practices, legislation, governance and climate data and areas for improving knowledge about the private sector's contribution to closing the climate gaps, which clearly adds to knowledge in this field. This section outlines the major findings.

\subsection{Overarching Frameworks and Governance}

In terms of the overarching frameworks for the private sector's involvement, London and Copenhagen have instigated well-informed climate policies in compliance with national recommendations, global goals, and research. The implementation on the ground depends on how much governance, legislative, and financial frameworks in the two cities have been able to commit/interest the private actors. Copenhagen offers a more systematic approach to private actors' involvement in terms of landowners and developers than London since its local planning processes are binding to public and private actors and regulations are clearer, which in turn helps to deliver the climate goals. Meanwhile, London faces a significant challenge related to its building regulations, which leaves space for interpretation and ambiguity and falls short of London's own climate ambitions. London also faces a challenge related to its decentralised steer between local boroughs.

Governance aspects impact the implementation of measures and processes in the two cities. Both cities essentially feature liberal economy models. Nevertheless, the UK gives more power to private actors in the property market, leaving it practically up to them to interpret sustainability. EIA is only required in a small number of projects and is essentially a flexible requirement, since deciding on carrying out an EIA is determined in dialogue with the developers. The same condition applies to environmental performance evaluation for buildings (in the UK referred to as 'BREEAM'). While some local London boroughs require BREEAM for larger projects, it is not a general legal requirement in private investments. City governance in London has posed a challenge to many strategies, including implementing Smart City initiatives, which require coordinating planning decisions across the different local authorities and initiating simultaneous and synergic action.

In this context, 'city leadership' appears as an essential factor determining the effectiveness of policies and their implementation to achieve the sustainability and climate targets and create clear and consistent frameworks for the involvement of the private actors. It is important for ensuring synergies and compliance of all initiatives and projects with policy aims and sector development goals. The analysis of processes and networking patterns in Copenhagen and London, especially around the North Harbour in Copenhagen, the new network, LETI in London and Barking Riverside London, reveals that even in a market economy setting, public agency's leadership is crucial for embracing local initiatives. It is crucial to facilitate and encourage necessary action, coordinate interests while ensuring sustainability concerns and monitor impacts. Furthermore, the analysis reveals an important role for the state in ensuring suitable frameworks, particularly around monitoring climate data, standardisation and climate finances, the necessity to fund specific projects upfront, and ensure that relevant partners are on board.

Both London and Copenhagen demonstrate the importance of integrating climate benefit into urban development where ecology, society, and economy can benefit. This requires the instigation of 
holistic visions that support green growth and healthy city and deal with climate challenges within a clear city leadership that ensures a qualitative private sector's engagement. This aspect invites to explore new opportunities in existing and new urban regeneration areas.

The visibility of innovative projects can be an essential strategy to encourage positive practices and incentivise private actors. Copenhagen has employed this strategy in North Harbour. The example of the Eco-Friendly Neighbourhood at Copenhagen's North Harbour reveals how important it is to curate, develop and showcase new holistic and integrated planning concepts to demonstrate how to deliver projects that contribute to a sustainable environment, economic development, and liveable city, and the role of city design and innovation in eco-technology where the private sector makes a significant contribution. At the same time, the North Harbour project draws attention to the fact that, while showcasing projects and competitive processes can be helpful to prompt innovation, create consensus around new concepts, and incentivise the private actors, it is crucial to explore the extent they inspire practices in other city areas with different contexts and on a city level and their impacts.

The challenge remains in how to commit developers to include relevant measures in city areas where they do not see a major benefit. These actors are usually interest-driven and not typically engaged in applying compliance measures if they are thought to incur costs or threaten their projects' visibility. This interest-driven practice has been recorded in several projects as highlighted earlier, for example with regards to the delivery of social housing in London. Perry [129] highlights how initial requirements to include a certain percentage of affordable housing have been compromised based on claims that a higher percentage would affect the viability of the projects. Therefore, the paper suggests the importance of a firm local authority role and project models demonstrating planning concepts, mutual benefit, and investment feasibility in the long term.

There is a gap in knowledge about the impact of the private sector through its different roles. There is, therefore a need to establish a robust methodology exploring the private sector's contribution to bridging the climate gap through its complex and different involvements highlighted earlier, considering internal and external business processes, the life cycle of projects, and the relationship between goals, actions and impacts. Meanwhile, many benefits to the environment and sustainability can be drawn from improving business processes. Awareness has recently increased amongst leading industries in both cities about the necessity of making the businesses aware of expenses and climate costs of their footprint, something that will benefit both the industries and climate efforts and would serve in discussing climate financing [42,110]. At the same time, it is important to highlight the opportunities for more effective budgets related to improving and integrating business processes and circular economy principles and including features in the projects that would contribute added value to projects and reward investments.

Regarding whether city size has played a role in climate response, attention has been drawn to the fact that the existing building mass to adapt in London and the city land, including underused land, are more substantial as well as the population and their requirements and the more sophisticated infrastructure-all require more resources and complex organisational frameworks. London is a multi-cultural global city, with approximately 8.9 million inhabitants compared to approximately 600,000 in Copenhagen in a region of 1,845,000 (2019). This necessitates more efforts when behavioural adaptations and consensus are needed, for example, regarding the shift from private transportation to cycling. Based on this research, there is a shorter distance between the city authority and the citizens in Copenhagen, and a few major debate platforms on architecture and innovation where initiatives are often coordinated to showcase pilot projects. This makes it easier in Copenhagen to communicate initiatives throughout the city and engage with different actors. Interestingly, earlier research on Danish local governments and their involvement in climate initiatives revealed that larger Danish cities have been more able to develop and implement measures and be involved with innovation due to their resources and skilled population.

Finally, climate finances have an important role and require a more in-depth exploration to advance the comparison of the two cities in their local and national frameworks. 


\subsection{Main Roles for Private Involvement in London and Copenhagen}

Both London and Copenhagen demonstrate all the variations of private sector's engagement in sustainable urban development, as summarised below (Table 2). They show that the private sector, in terms of consultancy companies and technology providers, makes a significant contribution to innovation around sustainability and climate adaptation and mitigation through building and adaptation activities, provision of infrastructure, development of new technologies, and new plan and design concepts. The private companies also deliver advisory on different policy and sustainability aspects and contribute to information networks. Its participation in experimentation, however, seems to rely on support from the public sector as we saw in Energy Lab Nordhavn.

The table shows that all four types of private-sector engagement are represented in both cases.

A particularly strong emphasis in both cases is on the prudent use of resources (role 1), particularly those associated with energy efficiency. Private sector contributions here emerge in terms of economic circularity and thus, an emphasis on using regenerative energy sources and sustainable materials in projects and building processes. The policy tools are quite similar in both cases, featuring a combination of energy-efficiency standards and incentives (taxes, subsidies) for sustainable construction. The London case shows a stronger focus on voluntary initiatives by private parties, while the Copenhagen case relies more strongly on public-sector support for private sector action regarding the sustainable use and consumption of resources.

The cases differ to a degree on private sector engagement in assessing the environmental impacts from urban development changes they facilitate or initiate (role 2). Environmental Impact Analysis (EIA) and environmental performance assessment are more widely prescribed in Denmark and thus more prominent in the Copenhagen case. An emerging focus on addressing environmentally damaging effects from urban development is around ideas to assess impacts throughout the life cycle of projects and ongoing business processes. There is a recent interest in both cases to institutionalise life cycle approaches further and, thus, strengthen reporting mechanisms for private actors to monitor potential environmental loads and resource use in cities.

The role of private actors in technological innovation, experimentation, and smart technology (role 3 ) is visible, for example, through renewable energy companies. There is a key role for pilot projects, illustrating a voluntary role for private actors and investors again, and illustrating the importance of innovation and learning in both cases.

Knowledge production and public engagement (role 4) are crucial anyway, with both cases featuring several platforms for public-private interaction. The Copenhagen case relies somewhat more on public-sector support for private-sector involvement in innovation and knowledge production. Knowledge production involves several independent private platforms in the London case.

Overall, the study points to a broader 'mainstreaming' of private engagement in sustainable urban-development practice. Strategic choices over the last decade show patterns of using well-established basic environmental standards. The study also shows an increasingly expanding voluntary role of the private sector over the whole range of actors (investors, landowners, developers, contractors, consultants, businesses).

The generic focus in the cases is on facilitating learning processes. These processes involve pilot projects and the establishment of platforms for collaborative learning. The cases show evidence of varied types of involvement in learning and knowledge production, highlighting projects, and the importance of discussing social and environmental concerns. The article establishes the importance of large-scale pilot projects (such as the North Harbour case in Copenhagen), enabling flexibility and adaptability as they demonstrate how climate adaptation measures can be included in a large city setting. These projects can be experimental, bringing together many actors and enjoying visibility. An obvious critical point among both public and private actors should be that knowledge about the implementation of sustainability and climate adaptation strategies should not become an exclusive responsibility of a limited group only. Instead, they should involve knowledge forums gathering actors from the private, the public, and NGOs, and facilitate broader interaction. 
Table 2. Private involvement roles for sustainable urban-development practice in London and Copenhagen.

\begin{tabular}{|c|c|c|}
\hline Role of the Private Sector & Copenhagen & London \\
\hline $\begin{array}{l}\text { 1. Clarify and stimulate the prudent use of resources } \\
\text { typical for urban environments: green, water, land, air. }\end{array}$ & $\begin{array}{l}\text { - Compliance of the private sector through building and planning regulations and } \\
\text { energy-efficiency standards. } \\
\text { Qualitative involvement of the private sector around public sustainability projects } \\
\text { focusing on urban innovation. Broader involvement of the private sector in innovation } \\
\text { and knowledge production within public sector support, contributing awareness } \\
\text { around resource use, sustainability, and climate benefits. } \\
\text { - Application of modeling involving climate cost of business processes through all stages. } \\
\text { - Considerations around greater synergy between the use of renewable energies and } \\
\text { climate taxes. }\end{array}$ & $\begin{array}{l}\text { - Compliance of the private sector through building and planning regulations and } \\
\text { energy-efficiency standards. } \\
\text { Private sector role regarding efficient resources specific to projects, through } \\
\text { permit negotiations. } \\
\text { - Increasing focus on voluntary Green Infrastructure and Recovery supported through } \\
\text { regulative and funding frameworks and coordination mechanisms. } \\
\text { - Several private forums involved in standards and advisory around sustainability and } \\
\text { climate. Considerations to make public funding sources to businesses conditional based } \\
\text { on assessing energy use through the life cycle of projects. }\end{array}$ \\
\hline $\begin{array}{l}\text { 2. Assessing sustainability impacts from urban } \\
\text { development }\end{array}$ & $\begin{array}{l}\text { - Private sector undertakes assessments of environmental and sustainability impacts in } \\
\text { compliance with the law. } \\
\text { - Plans, programmes and specific projects legally require EIA in all cases of 'potential' } \\
\text { environmental risk and impacts on sustainable development. } \\
\text { - Sustainability is assessed in terms of its broad implications on the environment, } \\
\text { localities, people, cultural heritage, etc. } \\
\text { - Recent awareness around the importance of assessing impacts throughout different } \\
\text { business' processes. }\end{array}$ & $\begin{array}{l}\text { Discussion around for a more systematic and committing approach to private actors. } \\
\text { EIA only required for a small number of projects. } \\
\text { EIA processes are defined and carried in dialogue with developers. Environmental } \\
\text { performance in building and construction not a general requirement but required for all } \\
\text { public projects. } \\
\text { - Focus on assessment of impacts through the lifecycle of projects. }\end{array}$ \\
\hline $\begin{array}{l}\text { 3. Contribute investments into technological } \\
\text { innovation, experimentation and smart technology. }\end{array}$ & $\begin{array}{l}\text { - Growth and leadership of renewable energy companies, for example, production of } \\
\text { wind energy and solar power. } \\
\text { The private sector actively contributes innovative solutions within collaborative } \\
\text { networks in visible pilot urban projects } \\
\text { - Contribution to Danish Cleantech Hub-a non-profit public-private initiative } \\
\text { promoting sustainable Danish city solutions } \\
\text { - Participation in bids and competitions. } \\
\text { - Private sector investments are encouraged through state green funding and green } \\
\text { finances generally. }\end{array}$ & $\begin{array}{l}\text { - Growth in renewable energy companies and private investment in renewable energies. } \\
\text { - Aarge-scale investments in environmental and climate consultancy and networks. } \\
\text { Active contribution in pilot projects, but this can be strengthened and made more } \\
\text { - Particicipation in in bids and comat at the citity level. } \\
\text { - Need to review public climate finances and funding sources to local authorities and } \\
\text { businesses to encourage more involvement of the private sector in technological } \\
\text { innovation, sustainable urbanism, and climate adaptation and mitigation. }\end{array}$ \\
\hline $\begin{array}{l}\text { 4. Involvement in public engagement aimed at } \\
\text { imagining, partnering and evaluating sustainable } \\
\text { futures through collaborative governance. }\end{array}$ & $\begin{array}{l}\text { - Involvement through focused city and government-facilitated debate platforms. } \\
\text { - Involvement under a strong City-Leadership on sustainability and climate goals and } \\
\text { their implementation. } \\
\text { - Making knowledge available through company websites. }\end{array}$ & $\begin{array}{l}\text { - Involvement through several forums, organised through both public and } \\
\text { private institutions. } \\
\text { - Facilitating learning and community platforms, skills building and increasing general } \\
\text { citizens' awareness in some pilot projects. This needs to be encouraged in } \\
\text { different contexts. } \\
\text { - Making knowledge available through company websites. }\end{array}$ \\
\hline
\end{tabular}


The generic focus is also on strategies by public agencies such as city governments to incentivise private actors and then monitor sustainability effects. An increasingly strong emphasis materialising in practice is around innovation and improving business processes through circular concepts and integration to better deliver the climate goals and more effectiveness in budgets. The analysis points to the critical importance of addressing climate information gaps, and a general lack of detailed systematic reporting on investments and contributions to $\mathrm{CO}_{2}$ reduction in cities overall, while relating this to the lifecycle of individual projects.

\section{Conclusions and Recommendations}

The article has taken as a starting point the question of what form of private sector engagement may feature in European sustainable urban-development practice, specifically for strategic cities like London and Copenhagen, given ongoing gaps in climate policies relevant to cities. An overall aim was to clarify private sector contributions to delivering climate goals in urban contexts. To understand this expectation in a realistic perspective and identify gaps, the article has explored policy, governance, and regulative frameworks for the private sector's involvement in urban development, sustainability, and climate efforts in two European cities; London and Copenhagen. Both cities have included climate adaptation and mitigation policies and measures and succeeded in significantly reducing emission levels since the early 2000s, with Copenhagen currently reaching a lower emission rate per capita than London, but with gaps in both cities that need to be addressed. Attention has been drawn to the necessity of considering the contribution of different forms of involvement of the private sector in the built environment, ranging from (1) a role in stimulating the prudent use of resources in urban environments through compliance with regulations, investment in the built environment, and consultancy; (2) assessment of sustainability impacts from urban development; (3) investments into technological innovation, experimentation, and smart technology; and (4) involvement in public engagement and debate platforms and contribution to the knowledge base around sustainable futures. The article has highlighted differences in governance and regulatory frameworks between the two cities impacting the private sector's engagement through its different roles. The article has also highlighted different views on the private sector's contribution to sustainability through different forms of partnership in urban regeneration. These aspects deserve to be taken as a starting point to establishing a more generic methodology for assessing private-sector contributions to closing climate gaps and improving policies and regulations, governance, and financial frameworks.

In conclusion the article emphasises the importance of strong 'city leadership' for promoting sustainable growth, ensuring synergies and suitable frameworks for private-sector engagement through its various forms, and monitoring sustainability impacts.

Reaching climate goals and improving public and private actors' performance require cities to continue their efforts and develop competencies in new areas. The evidence suggests that the following recommendations can be made:

- Adopt a consistent methodology acknowledged at the city and national levels to explore and assess the private sector's contribution to bridging the climate gap through its different involvements, considering internal and external business processes and projects' life cycles.

- Continue developing, encouraging and supporting appropriate energy modelling schemes while considering the life energy of buildings and urban typologies, and develop appropriate methods and indicators to assess performance that all parties, including the public and the private sector, can agree upon and stick to.

- Encourage the integration of approaches and processes at all stages of design, construction/implementation, and management, as many opportunities benefiting sustainability aims can be lost in parallel and segregated design processes. It is also vital to explore businesses' internal and external capabilities and chain relationships, which may shape adaptation responses, and promote a circular economy, including construction and business models. 
- Expand approaches from climate adaptation in buildings and inclusion of small-scale climate measures, such as green walls and SUDS, to include a broader urban perspective dealing with diverse urban structures, mobility patterns, and smart networks and enabling innovation in planning and green growth. This perspective should capitalise on an ecological approach to place-making at the city scale, supporting multiple environmental, social, health, and economic benefits while involving communities and the private actors in delivering the different measures.

- Need to update regulatory frameworks, business models, and collaboration forms regularly, particularly to facilitate learning processes around pilot projects and around ideas about the future of cities more in general and build consensus around overall policies and implementation.

- Need to establish proper and adaptable data records acknowledged at the city and national levels to which all parties can contribute to full transparency in terms of $\mathrm{CO} 2$ reductions and cost-shared by different actors and across all stages, including the users. This can be part of intelligent Big Data on energy reduction in the built environment and how this can be met across different sectors, including water, waste, and other infrastructure and smart management of these aspects.

- Encourage the dynamics of local companies involved in technology and innovation to contribute to climate efforts and local development.

- Contribute to and continue to encourage conceptual and practical knowledge-production and knowledge platforms to cover new areas related to climate adaptation and mitigation while ensuring synergies where necessary, broader participation, and effective use of outcomes.

The research reveals the need for more studies on the private sector's role in delivering climate goals through specific projects in the built environment within more holistic, innovative, and adaptable urban development and sustainability approaches. It is also vital to develop perspectives on the different incentives available through climate finances and other sources. The research calls for studying the implications for local areas and how to improve planning and governance processes and enable holistic visionary approaches and consensus around sustainable development to benefit good place-making in all terms and the climate.

Funding: This research received no external funding.

Acknowledgments: I would also like to thank Johan Woltjer very much for his input and valuable comments on the earlier drafts of the paper.

Conflicts of Interest: The authors declare no conflict of interest.

\section{References}

1. United Nations. Transforming Our World: The 2030 Agenda for Sustainable Development; Resolution Adopted by the General Assembly on 25 September 2015; United Nations: New York, NY, USA, 2015.

2. World Metrological Organisation. Climate Agenda; World Climate Programme. Available online: https: //www.wmo.int/pages/prog/wcp/ccl/aboutccl/climate_agenda.html (accessed on 20 August 2020).

3. United Nations. Framework Convention on Climate Change. Report of the Conference of the Parties on its twenty-first session, held in Paris from 30 November to 13 December 2015, Part one: Proceedings. Available online: https://unfccc.int/sites/default/files/resource/docs/2015/cop21/eng/10.pdf (accessed on 15 July 2020).

4. United Nation. United Nations Secretariat Climate Action Plan. Available online: https://www.un.org/ management/sites/www.un.org.management/files/united-nations-secretariat-climate-action-plan.pdf (accessed on 10 June 2020).

5. Dekker, S. Cities Leading Climate Action: Urban Policy and Planning; Routledge: London, UK, 2018.

6. UNEP. Emission Gap Report; UNEP: Nairobi, Kenya, 2019.

7. OECD. The Economic Consequences of Climate Change; OECD: Paris, France, 2015.

8. European Environment Agency. EU Greenhouse Gas Emissions Kept Decreasing in 2018, Largest Reductions in Energy Sector. Available online: https://www.eea.europa.eu/downloads/ ca1b98d013a846468169173a8cfdf10c/1591869121/eu-greenhouse-gas-emissions-kept.pdf (accessed on 10 June 2020). 
9. European Environment Agency. Progress of the European Union towards its Greenhouse Gas Emission Targets. Briefing. Available online: https://www.eea.europa.eu/themes/climate/trends-and-projections-ineurope/trends-and-projections-in-europe-2016/progress-in-reducing-total-eu. (accessed on 10 June 2020).

10. Royal Town Planning Institute. Five Reasons for Climate Justice in Spatial Planning; RTPI: London, UK, 2020.

11. Huang-Lachmann, J.T.; Lovett, J.C. How Cities Prepare for Climate Change: Comparing Hamburg and Rotterdam. Cities 2016, 54, 36-44. [CrossRef]

12. Gonzalez-Perez, M.A. Climate Change and the 2030 Corporate Agenda for Sustainable Development. Adv. Sustain. Environ. Justice 2016, 19, 1-6.

13. Moore, S.; Bunce, S. Delivering Sustainable Buildings and Communities: Eclipsing social concerns through private sector-led urban regeneration and development. Local Environment. Int. J. Justice Sustain. 2009, 14, 601-606. [CrossRef]

14. World Economic Forum. Global Risk Report; World Economic Forum: Cologny, Switzerland, 2019.

15. Lorenz, S.; Porter, J.J.; Dessai, S. Identifying and tracking key climate adaptation actors in the UK. Reg. Environ. Chang. 2019, 19, 2125-2138. [CrossRef]

16. Talandier, M. Are There Urban Contexts that are Favourable to Decentralised Energy Management? Cities 2018, 82, 45-57. [CrossRef]

17. Ministry of Housing, Communities and Local Government. National Planning Policy Framework. UK, 2012. Available online: https://webarchive.nationalarchives.gov.uk/20180608095821/https://www.gov.uk/ government/publications/national-planning-policy-framework--2 (accessed on 25 May 2020).

18. Ministry of Housing, Communities and Local Government. National Planning Policy Framework. UK, 2018. Available online: https://webarchive.nationalarchives.gov.uk/20181206183454/https://www.gov.uk/ government/publications/national-planning-policy-framework--2 (accessed on 25 May 2020).

19. Ministry of Housing, Communities and Local Government. National Planning Policy Framework. UK, 2019. Available online: https:/assets.publishing.service.gov.uk/government/uploads/system/uploads/attachment_ data/file/810507/NPPF_Feb_2019_print_revised.pdf (accessed on 28 June 2020).

20. Department for Environment, Food and Rural Affairs. The National Adaptation Programme and the Third Strategy for Climate Adaptation Reporting; DEFRA: London, UK, 2018.

21. Building Regulations (UK). Approved Document Part L: Conservation of Fuel and Power; Ministry of Housing, Communities \& Local Government: London, UK, 2018.

22. Flood and Water Management Act. 2010. Available online: https://www.legislation.gov.uk/ukpga/2010/29/ contents (accessed on 20 June 2020).

23. Climate Change Act. 2008. Available online: https://www.legislation.gov.uk/ukpga/2008/27/contents (accessed on 20 June 2020).

24. Greater London Authority Act. 2007. Available online: https://www.legislation.gov.uk/ukpga/2007/24/ contents (accessed on 20 June 2020).

25. Department for Communities and Local Government. Code for Sustainable Homes; Department for Communities and Local Government: London, UK, 2010.

26. Cabinet Office. Common Minimum Standards for Procurement of the Built Environments in the Public Sector; Cabinet Office: London, UK, 2012.

27. Localism Act. 2011. Available online: https://www.legislation.gov.uk/ukpga/2011/20/contents/enacted (accessed on 20 May 2020).

28. Environment Agency. Thames Catchment Flood Management Plan. Summary Report; Environment Agency: London, UK, 2009.

29. Greater London Authority. Draft London Plan-Consolidated Changes Version-Clean; Greater London Authority: London, UK, 2019.

30. Mayor of London. The London Plan. The Spatial Development Strategy for London Consolidated with Alterations Since 2011; Greater London Authority: London, UK, 2016.

31. Mayor of London. London Environment Strategy; Greater London Authority: London, UK, 2018.

32. Mayor of London. London Climate Change Adaptation Strategy; Greater London Authority: London, UK, 2011.

33. Mayor of London. Delivering London's Energy Future. The Mayor's Climate Change Mitigation and Energy Strategy; Greater London Authority: London, UK, 2011.

34. Mayor of London. Energy Assessment Guidance. Greater London Authority Guidance on Preparing Energy Assessments as Part of Planning Applications; Greater London Authority: London, UK, 2018. 
35. Lambeth. Vauxhall. Planning Document; Lambeth: London, UK, 2013.

36. Environment Agency. Thames Estuary Plan 2100. Managing Flood Risk Through London and the Thames Estuary; Environment Agency: London, UK, 2012.

37. Port of London Authority. Environmental Report; Port of London Authority: London, UK, 2019.

38. UKGBC. Net Zero Carbon Buildings: A Framework Definition; Green Building Council: London, UK, 2019.

39. London Energy Transformation Initiative. Climate Emergency Design Guide; LETI: London, UK, 2020.

40. London Energy Transformation Initiative. Embodied Carbon Primer; LETI: London, UK, 2020.

41. Future of London and GVA. Making Housing Delivery Models Work for London; Future of London: London, UK, 2017.

42. Shorthouse, R.; Hall, P. Delivering Net Zero. Building Britain's Resilient Recovery; Bright Blue and WSP: London, UK, 2020.

43. Regeringen. Et bæredygtigt Danmark—Udviking i Balance. Available online: https://mst.dk/media/91913/etbaeredygtigt-danmark_udvikling-i-balance_web_a.pdf (accessed on 10 June 2020).

44. Danish Ministry of Environment. Spatial Planning in Denmark; Ministry of the Environment: Copenhagen, Denmark, 2012.

45. Erhvervsministeriet. Landsplanredegørelse 2019. Vækst og Udvikling Gennem Fysisk Planlægning-Bedre Rammer for Virksomheder, Borgere og Kommuner i hele Landet; Erhvervsministeriet: Copenhagen, Denmark, 2019.

46. Forslag til Lov om Klima . 2019. Denmark. Available online: https://www.retsinformation.dk/eli/ft/ 201912 L00117 (accessed on 3 September 2020).

47. Danish Ministry of Climate, Energy and Utilities. Denmark Integrated National Energy and Climate Plan; Danish Ministry of Climate, Energy and Utilities: Copenhagen, Denmark, 2019.

48. Klimatilpasning. Klimatilpasning i Kommunerne; Miliøstyrelsen: Copenhagen, Denmark, 2018.

49. Erhvervsstyrelsen. Oversigt over Nationale Interesser i Kommuneplanlægning; Erhvervsstyrelsen: Copenhagen, Denmark, 2018.

50. Bekendtgørelse af lov om Planlægning, 2007. Available online: https://www.retsinformation.dk/eli/lta/2007/ 813 (accessed on 20 May 2020).

51. Bekendtgørelse af lov om Planlægning, 2018. Available online: https://www.retsinformation.dk/eli/lta/2018/ 287 (accessed on 20 May 2020).

52. Bekendtgørelse af Byggeloven, 2016. Available online: https://www.retsinformation.dk/eli/lta/2016/1178 (accessed on 20 May 2020).

53. Bekendtgørelse af lov om miljøvurdering af planer og programmer og af konkrete projekter (VVM). 2018. Available online: https://www.retsinformation.dk/eli/lta/2018/1225 (accessed on 20 May 2020).

54. Energi-, Forsynings- og Klimaministeriet. Energiaftale 2018. Available online: https://www.regeringen.dk/ publikationer-og-aftaletekster/energiaftale/ (accessed on 10 August 2020).

55. Danish Knowledge Centre for Energy Saving in Buildings. Energy Requirements of BR18. A Quick Guide for the Construction Industry on the Danish Building Regulations 2018; Energistyrelsen: Copenhagen, Denmark, 2018.

56. Energistyrelsen. Støtte til Vedvarende Energi [for] Elproduktion. Available online: https://ens.dk/ ansvarsomraader/stoette-til-vedvarende-energi (accessed on 20 August 2020).

57. Københavns Kommune. Københavns Kommuneplan 2019-Verdens By Med Ansvar; Københavns Kommune: Copenhagen, Denmark, 2019.

58. Københavns Kommune. Den Tænkende Storby. Københavns Kommuneplan 2009; Københavns Kommune: Copenhagen, Denmark, 2009.

59. Københavns Kommune. Den Tænkende Storby. Kommuneplanstrategi 2007; Københavns Kommune: Copenhagen, Denmark, 2007.

60. Københavns Kommune. Miljø Metropolen. Copenhagen Climate Adaptation Plan; City of Copenhagen: Copenhagen, Denmark, 2011.

61. City of Copenhagen. Copenhagen Cloudburst Management Plan 2012; City of Copenhagen: Copenhagen, Denmark, 2012.

62. City of Copenhagen. Copenhagen First Climate Resilient Neighbourhood; City of Copenhagen: Copenhagen, Denmark, 2016.

63. Københavns Kommune. Arhusgadekvarteret $i$ Nordhavn. Lokalplan nr. 463. Adopted by the Municipal Council in 2011; Københavns Kommune: Copenhagen, Denmark, 2011. 
64. Københavns Kommune, Center for Bydesign. Værktøj til Bæredygtig Byudvikling; Københavns Kommune: Copenhagen, Denmark, 2009.

65. CPH City and Port Development. Nordhavnen Urban Strategy; CPH City and Port Development: Copenhagen, Denmark, 2009.

66. IPPC. Global Warming of $1.5^{\circ} \mathrm{C}$-An IPCC Special Report on the Impacts of Global Warming of $1.5^{\circ} \mathrm{C}$ above Pre-Industrial Levels and Related Global Greenhouse Gas Emission Pathways, in the Context of Strengthening the Global Response to the Threat of Climate Change, Sustainable Development, and Efforts to Eradicate Poverty; IPCC: Geneva, Switzerland, 2019.

67. Evans, A. Private Sector Partnership for Sustainable Development. In Development Co-Operation Report 2015 Making Partnerships Effective Coalitions for Action; OECD Publishing: Paris, France, 2015.

68. Nelson, J. Partnership for Sustainable Development: Collective Action by Business, Governments and Civil Society to Achieve Scale and Transform Markets; Harvard Kennedy School, Business and Sustainable Development Commission, and Corporate Responsibility Initiative. Available online: http://s3.amazonaws. com/aws-bsdc/PartnershipsforSD.pdf (accessed on 20 September 2020).

69. Scheyvens, R.; Banks, G.; Hughes, E. The Private Sector and the SDGs: The Need to Move Beyond 'Business as Usual'. Sustain. Dev. 2016, 24, 371-382. [CrossRef]

70. Streck, C.H. Filling in for Governments? The Role of the Private Actors in the International Climate Regime. J. Eur. Environ. Law. 2020, 17, 5-28. [CrossRef]

71. Macomber, J. The Role of Finance and Private Investment in Developing Sustainable Cities. J. Appl. Corp. Financ. 2011, 23, 64-74. [CrossRef]

72. Henry, S. Governments Alone Cannot Halt Climate Change. How Can the Private Sector Help? World Economic Forum: Cologny, Switzerland, 2017.

73. European Investment Bank. The EIB Circular Economy Guide-Supporting the circular transition; EIB: Luxembourg, 2020.

74. MacArthur Foundation. Completing the Picture: How the Circular Economy Tackles Climate Change; MacArthur Foundation: Cowes, UK, 2019.

75. Alkhani, R. Waterfront Redevelopment and Urban Revitalization in the Changing Industrial Port City. Ph.D. Thesis, Royal Danish Academy of Fine Arts, Copenhagen, Denmark, 2007.

76. Hood, C. A Public Management for all Seasons? Public Adm. Wiley 1991, 69, 3-19. [CrossRef]

77. Osborne, S. The New Public Governance. Public Manag. Rev. 2006, 8, 377-387. [CrossRef]

78. Koppenjan, J.F.M.; Enserink, B. Public-Private Partnerships in Urban Infrastructures: Reconciling Private Sector Participation and Sustainability. Public Admin. Rev. 2009, 69, 284-296. [CrossRef]

79. Pinz, A.; Roudyani, N.; Thaler, J. Public-Private Partnerships as Instruments to Achieve Sustainability-Related Objectives: The state of the art and a research agenda. Public Manag. Rev. 2018, 20, 1-22. [CrossRef]

80. UDMW. Deptford Urban Design. Student Report. Urban Design Public Realm Module; University of Westminster: London, UK, 2020.

81. Lehmann, S. Urban Regeneration. A Manifesto for Transforming UK Cities in the Age of Climate Change; Palgrave Macmillan: London, UK, 2019.

82. Blue-Green Cities. Delivering and Evaluating Multiple Flood Risk Benefits in Blue-Green Cities. Available online: http://www.bluegreencities.ac.uk/documents/blue-green-cities-key-project-outputs.pdf (accessed on 20 June 2020).

83. Sinnett, D.; Smith, N.; Burgess, S. Handbook on Green Infrastructure: Planning, Design and Implementation; Edward Elgar Publishing: Cheltenham, UK, 2016.

84. UNEP. The Nature Based Solutions for Climate Manifesto, Developed for the UN Climate Action Summit 2019; UNEP: Nairobi, Kenya, 2019.

85. Jung, C.; Murphy, L. Transforming the Economy after Covid-19: A Clean, Fair and Resilient Recovery; Institute for Public Policy Research: London, UK, 2020.

86. Restemeyer, B.; Van den Brink, M.; Woltjer, J. Resilience Unpacked: Framing of 'uncertainty' and 'adaptability' in long-term flood risk management strategies in the regions of London and Rotterdam. Eur. Plan. Stud. 2018, 36, 1559-1579. [CrossRef]

87. Caloffi, A.; Pryke, S.; Sedita, S.R.; Siemiatycki, M. Public-Private Partnerships and Beyond: Potential for innovation and sustainable development. Politics Space 2017, 35, 739-745. [CrossRef] 
88. OECD. The Innovation Imperative: Contributing to Productivity, Growth and Wellbeing; OECD Publishing: Paris, France, 2015.

89. Johnstone, N.; Pilat, D. Business Innovation and Climate Change: Policy makers must favour dynamism. Available online: https://oecdobserver.org/news/fullstory.php/aid/5313/Business_innovation_and_climate_ change:_Policy_makers_must_favour_dynamism.html (accessed on 20 September 2020).

90. Himmel, M.; Siemiatycki, M. Infrastructure Public-Private Partnerships as Drivers of Innovation? Lessons from Ontario, Canada. Environ. Plan. C Polit. Space 2017, 35. [CrossRef]

91. Schot, J.; Steinmueller, W.E. Three Frames for Innovation Policy: R\&D, systems of innovation and transformative change. Res. Policy 2018, 47, 1554-1567.

92. Madsen, H.M.; Mikkelsen, P.S.; Blok, A. Framing Professional Climate Risk Knowledge: Extreme weather events as drivers of adaptation innovation in Copenhagen, Denmark. Environm. Sci. Policy 2019, 98, 30-38. [CrossRef]

93. Uyarra, E.; Edler, J.; García-Estévez, J.; Georghiou, L.; Yeow, J. Barriers to Innovation through Public Procurement: A Supplier perspective. Technovation 2014, 34, 631-645. [CrossRef]

94. Gans, J.S. Innovation and Climate Change Policy. Am. Econ. J. 2012, 4, 125-145. [CrossRef]

95. United Nations Office for Disaster Risk Reduction (UNDRR). Disaster Resilience Scorecard for Cities; UNDRR: Geneva, Switzerland, 2017.

96. The Rockefeller Foundation and Arup. City Resilience Index; ARUP: London, UK, 2014.

97. Department of Business, Energy and Industrial Strategy. 2018 UK Green House Emissions, Final Figures; Department of Business, Energy and Industrial Strategy: London, UK, 2020.

98. Webb, J.; Emden, J.; Murphy, L. All Hands to the Pump. A Home Improvement Plan for England; Institute for Public Policy Research (IPPR): London, UK, 2020.

99. Regerings Klimapartnerskaber (DK). Kommissorium for Grønt Erhvervsforum; Erhvervministeriet: Copenhagen, Denmark, 2019.

100. Greater London Authority. London Energy and Greenhouse Gas Inventory (LEGGI); GLA: London, UK, 2017.

101. Københavns Kommune. CO2—Regnskab for 2005; Københavns Kommune: Copenhagen, Denmark, 2008.

102. Københavns Kommune. CO2—Regnskab for 2018; Københavns Kommune: Copenhagen, Denmark, 2019.

103. Bailey, N. Housing at the Neighbourhood Level: A review of the initial approaches to neighbourhood development plans under the Localism Act 2011 in England. J. Urban. Int. Res. Placemaking Urban Sustain. 2017, 10, 1-14. [CrossRef]

104. Future of London. Housing Delivery Models. Available online: https:/www.futureoflondon.org.uk/2017/11/ 27/housing-delivery-models-press-release/ (accessed on 28 June 2020).

105. Danish Centre for Environment and Energy. Climate Adaptation in Local Governance: Institutional Barriers in Danish Municipalities; Aarhus University: Aarhus, Denmark, 2016.

106. Hofor. Klare Anbefalinger, Energilab København; Hofor: Copenhagen, Denmark, 2020.

107. US Global Change Research Programme. Climate Science Special Report. Fourth National Climate Assessment (NCA4); US Global Change Research Programme: Washington, DC, USA, 2017; Volume 1.

108. Statistiks Denmark. Green National Accounts for Denmark 2015-2016; Statistiks Denmark: Copenhagen, Denmark, 2018.

109. OECD. OECD Environmental Performance Reviews—Denmark; OECD: Paris, France, 2019.

110. COWI. New Tools to Put a Price on Companies' Climate Footprint. Available online: https://www.cowi.com/ about/news-and-press/climate-footprint (accessed on 23 July 2020).

111. Mathiason, N. Thousands of Affordable Homes Axed. Available online: https://www.theguardian.com/ society/2013/sep/18/thousands-affordable-homes-axed-councils (accessed on 18 July 2020).

112. Battersea Power Station. Positive Energy. The Impact on the Community, Economy and Environment of the Regeneration of Battersea Power Station. Available online: https://batterseapowerstation.co.uk/pdfs/ positive_energy.pdf (accessed on 25 July 2020).

113. Barking Riverside London. Barking Riverside London. Available online: https://barkingriverside.london/ about-the-development/ (accessed on 10 August 2020).

114. Office for National Statistics. UK Environmental Accounts. 2020. Available online: https://www.ons.gov.uk/ economy/environmentalaccounts/bulletins/ukenvironmentalaccounts/2020 (accessed on 20 July 2020).

115. London Climate Change Partnership (LCCP). Available online: http://climatelondon.org/lccp/ (accessed on 10 June 2020). 
116. UK Green Building Council Homepage. Who We Are. Available online: https://www.ukgbc.org/about-us/ (accessed on 28 August 2020).

117. UKGBC. Net Zero Carbon Buildings: A Framework Definition; UK Green Building Council: London, UK, 2020.

118. UKGBC. Making the Case for Green Infrastructure: Lessons from Best Practice; UK Green Building Council: London, UK, 2020.

119. UKGBC. Accelerator Cities; UKGBC: London, UK, 2020.

120. London Energy Transformation Initiative about. Available online: https://www.leti.london/about (accessed on 25 August 2020).

121. UKGBC, LETI, BBP. Net Zero Operational Carbon; LETI: London, UK, 2020.

122. Alkhani, R. Notes from the Webinar 'UK Net Zero. Collaborative Action on Climate Change', hosted by LETI, UKGBC, RIBA, CIBSE, Energyhub. Unpublished work. 2020.

123. Kenyon, P. Financing the Thames Tideway Super Sewer. Available online: https://www.tunneltalk.com/UKLondon-17June2014-Private-Infrastructure-Provider-sought-to-fund-construction-cost-of-25km-ThamesTideway-supersewer.php (accessed on 27 May 2020).

124. Tideway. Tideway-The Organisation. Available online: https://www.tideway.london/about-us/theorganisation/ (accessed on 20 August 2020).

125. Varghese, S. London Sure Sewer Won't Solve the City's Epic Poop Problem. Available online: https: //www.wired.co.uk/article/sewage-environment-climate-change-london (accessed on 10 June 2020).

126. Mayor of London. The London Green Fund. Available online: https://www.london.gov.uk/what-we-do/ funding/european-regional-development-fund/london-green-fund (accessed on 20 July 2020).

127. C40 Cities. C40 Good Practice Guides: London-London Green Fund. C40. Available online: https: //www.c40.org/case_studies/c40-good-practice-guides-london-london-green-fund (accessed on 5 July 2020).

128. Green Finance Taskforce. Accelerating Green Finance. A Report to Government by the Green Finance Taskforce. Available online: https://assets.publishing.service.gov.uk/government/uploads/system/uploads/ attachment_data/file/703816/green-finance-taskforce-accelerating-green-finance-report.pdf (accessed on 20 July 2020).

129. Perry, J. Developers are Skimping on Low-Cost Housing. Available online: https://www.theguardian. com/housing-network/2018/mar/19/affordable-homes-low-cost-rent-uk-planning-policy-governmentdevelopers (accessed on 17 July 2020).

(C) 2020 by the author. Licensee MDPI, Basel, Switzerland. This article is an open access article distributed under the terms and conditions of the Creative Commons Attribution (CC BY) license (http://creativecommons.org/licenses/by/4.0/). 